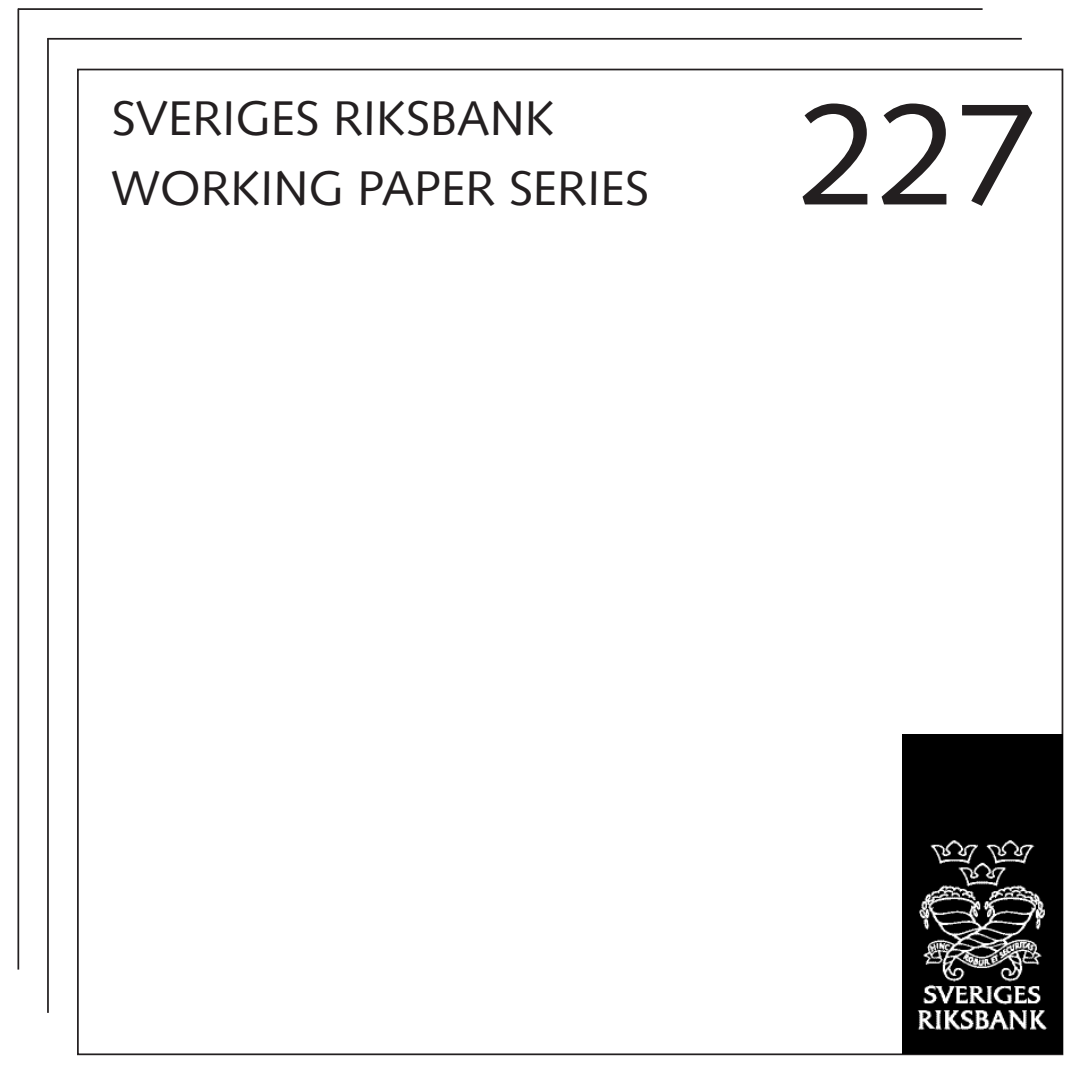

Re-Evaluating Swedish Membership in EMU: Evidence from an Estimated Model

Ulf Söderström

DECEMBER 2008 
WORKING PAPERS ARE OBTAINABLE FROM

Sveriges Riksbank • Information Riksbank • SE-103 37 Stockholm

Fax international: +4687870526

Telephone international: +4687870100

E-mail: info@riksbank.se

The Working Paper series presents reports on matters in the sphere of activities of the Riksbank that are considered to be of interest to a wider public.

The papers are to be regarded as reports on ongoing studies and the authors will be pleased to receive comments.

The views expressed in Working Papers are solely the responsibility of the authors and should not to be interpreted as reflecting the views of the Executive Board of Sveriges Riksbank. 


\title{
Re-Evaluating Swedish Membership in EMU: Evidence from an Estimated Model
}

\author{
Ulf Söderström* \\ Sveriges Riksbank Working Paper Series \\ No. 227 \\ December 2008
}

\begin{abstract}
I revisit the potential costs and benefits for Sweden of joining the Economic and Monetary Union (EMU) of the European Union. I first show that the Swedish business cycle since the mid-1990s has been closely correlated with the Euro area economies, suggesting that common shocks have been an important driving force of business cycles in Europe. However, evidence from an estimated model of the Swedish economy instead suggests that countryspecific shocks have been important for fluctuations in the Swedish economy since 1993, implying that EMU membership could be costly. The model also indicates that the exchange rate has to a large extent acted to destabilize, rather than stabilize, the Swedish economy, pointing to the costs of independent monetary policy with a flexible exchange rate. Finally, counterfactual simulations of the model suggest that Swedish inflation and GDP growth might have been slightly higher if Sweden had been a member of EMU since the launch in 1999, but also that GDP growth might have been more volatile. The evidence is therefore not conclusive about whether or not participation in the monetary union would be advantageous for Sweden.
\end{abstract}

Keywords: Monetary union, Open economy, Optimum Currency Area, DSGE model.

JEL Classification: E42, E58, F41.

\footnotetext{
*Sveriges Riksbank and CEPR. Address: Research Division, Monetary Policy Department, Sveriges Riksbank, 10337 Stockholm, Sweden; ulf.soderstrom@riksbank.se. This paper was prepared for the NBER conference on "Europe and the Euro" in October 2008. I am grateful for comments from, and discussions with, Carlo Altomonte, Carlo Favero, Nils Gottfries, Steinar Holden, Lars Jonung, Thomas Lindblom, Anders Vredin, and the editors, Alberto Alesina and Francesco Giavazzi. I also thank seminar participants at Sveriges Riksbank and Uppsala University, and participants at the NBER conference. And I am indebted to Malin Adolfson and Jesper Lindé for help with the estimated open-economy model. The views expressed in this paper are solely the responsibility of the author and should not be interpreted as reflecting the views of the Executive Board of Sveriges Riksbank.
} 


\section{Introduction}

When the Swedish government negotiated the treaty of accession to the European Union in 1993-94, the negotiations did not include an exemption to the third stage of the Economic and Monetary Union (EMU). In contrast to Denmark and the United Kingdom, which did obtain such exemptions, Sweden is therefore required by EU law to join EMU and adopt the euro as soon as the convergence criteria specified in the Maastricht treaty are fulfilled. Nevertheless, the Swedish Parliament (the Riksdag) decided in 1997 that Sweden would not join the Exchange Rate Mechanism (ERM) of the European Monetary System, and the Swedish central bank (Sveriges Riksbank) has followed a policy of inflation targeting with a flexible exchange rate since 1993. As a consequence, in the assessments made by the European Commission prior to the launch of EMU in 1999 and every two years since 2000, Sweden has been judged not to fulfill the criterion regarding exchange rate stability, which requires the member state to participate in the ERM (now the ERM II). Sweden therefore is a member state with a derogation from the third stage of EMU, but is not exempted from participation. ${ }^{1}$ A national referendum on Swedish participation in EMU was held in September 2003, and the result was a rejection of membership with $56 \%$ of the electorate voting against and $42 \%$ voting in favor. As a consequence, the Riksdag decision of 1997 remains in force, and Sweden remains outside EMU.

Ten years after the launch of EMU, I revisit the question of the potential costs and benefits for Sweden of joining the monetary union. I first (in Section 2) return to the report of the Calmfors Commission, the government commission assigned to study the consequences of EMU membership in 1995-96. I summarize the main conclusions of the Commission, and provide an updated evaluation of the arguments made in the report. Some of these arguments speak more strongly in favor of Swedish EMU membership today than in 1996, while others more clearly speak against membership.

I then take a broad look at European business cycles (in Section 3) and discuss the comovement between the Swedish and European economies. I show that European business cycles are closely correlated with each other, suggesting that business cycles in Europe are largely driven by common shocks. Although the large EMU member countries show stronger comovement with the Euro area, Sweden tends to be at least

\footnotetext{
${ }^{1}$ The assessments also conclude that Swedish legislation concerning the financial independence of the Riksbank and the Riksbank's integration into the European System of Central Banks (ESCB) is not consistent with the Maastricht Treaty and the statutes of the ESCB and the European Central Bank (ECB).
} 
as strongly correlated with the Euro area as some EMU members (for instance, Finland), and more closely correlated than Norway and the UK. This evidence indicates that membership in EMU would not be very costly for Sweden, and not more so than for some current EMU members.

Next, I present evidence from an estimated model of the Swedish economy. I discuss in Section 4 the importance of country-specific shocks for Swedish business cycle fluctuations since 1993, and I study the source and effects of fluctuations in the exchange rate. In contrast to the evidence in Section 3, the estimated model suggests that country-specific shocks are an important source of Swedish business cycle fluctuations, and therefore that participation in the monetary union may be costly. On the other hand, the model interprets most fluctuations in the exchange rate as caused by shocks to the exchange rate risk premium, rather than endogenous movements that help the economy adjust after disturbances to other sectors in the economy. As such risk premium shocks induce inefficient volatility in the macroeconomy, the benefits of having a flexible exchange rate may be small, speaking in favor of EMU membership (which to a large extent would eliminate exchange rate fluctuations, as the EMU countries represent around $60 \%$ of Swedish trade).

I then (in Section 5) use the model for a counterfactual experiment to evaluate what would have been the consequences for the Swedish economy if Sweden had joined EMU in January 1999. The simulations predict that Swedish membership in the monetary union might have led to slightly higher GDP growth and inflation, but also higher volatility in GDP growth. Furthermore, EMU membership might have implied higher inflation in 2004-05 when inflation was exceptionally low in Sweden. However, the effects of EMU membership are not dramatic, reflecting the strong comovement of the Swedish and Euro area economies in the last decade.

The model is silent on many relevant issues. I discuss some of these in Section 6, for instance, the impact of EMU on economic integration and labor markets, and whether Sweden has lost political influence in the EU by not participating in EMU. Finally, I conclude in Section 7 that, perhaps unsurprisingly, the evidence presented here is not conclusive about the whether the costs or the benefits of Swedish EMU membership dominate. These conclusions may however be sharpened by the outcome of the current financial crisis. 


\section{The Calmfors Commission}

Ahead of the Riksdag decision in 1997 concerning Swedish membership in EMU, the Swedish government appointed a commission (the "Calmfors Commission") to analyze the consequences of EMU and of Swedish membership in the monetary union. The Commission, composed of five economists and three political scientists, was appointed in October 1995 and delivered its report in October 1996, see Calmfors et al. (1996).

The Commission argued that monetary union would lead to small efficiency gains due to reduced transaction costs and exchange rate uncertainty and increased competition, speaking in favor of Swedish membership. However, these gains needed to be weighed against the adverse effects of large country-specific disturbances that could have severe consequences if they were not counteracted by independent monetary policy and exchange rate policy. While these large disturbances normally would not be an important problem, the Commission argued that independent monetary policy could be an important insurance against such extreme events.

An important argument in favor of Swedish EMU membership was deemed to be the potential loss of political influence within the EU if Sweden were to stay outside the monetary union.

All in all, the final assessment of the Commission was that the economic arguments did not favor participation, while the political arguments were in support of membership, but that the arguments against membership in 1999 were stronger than those in favor. Therefore, the Commission concluded that while Sweden should aim at future membership in the monetary union, it would be better not to join EMU in the first wave of $1999 .^{2}$

The Commission listed four main reasons for its conclusion:

1. EMU membership would be risky with the then high level of unemployment, as the economy would be particularly vulnerable to adverse shocks. After a long period with an unemployment rate around 2-3\%, the Swedish unemployment rate had increased quickly to above 9\% during the recession in 1992-93, and remained at this level until the late 1990s. (See also Figure 3 below.)

2. The already precarious fiscal situation also made membership risky, as fiscal measures would need to carry a larger burden of stabilization policy within the

\footnotetext{
${ }^{2}$ One member of the Commission dissented from this conclusion, arguing that the costs of monetary union would be large also in the longer term, and that Sweden should not join the monetary union in the future. See Gottfries (1996).
} 
monetary union, and a deterioration of the government finances would need to be followed by drastic countermeasures to satisfy the rules of the Stability and Growth Pact. The ratio of government debt to GDP was close to $75 \%$ in 1995-96, and the government deficit amounted to 9\% and 7\% of GDP in 1994 and 1995, respectively. Again, this difficult fiscal situation was partly caused by the recession in the early 1990s.

3. To ensure legitimacy among the electorate, the commission saw a need for a broad public debate concerning the monetary union before a definitive decision was taken. There had not been any extensive debate of EMU before the referendum concerning EU membership in 1994, as EMU membership was seen as an issue separate from EU membership.

4. The fact that only a subset of EU members were likely to join the monetary union, and, in particular, not Denmark and the UK, implied that the potential economic gains of membership seemed small, while the costs of staying outside in terms of lost political influence seemed limited. In 1996, many observers expected that only a small core of EU member states (consisting of Germany, France, the Benelux countries, Austria, and perhaps Finland and Ireland) would be able to qualify for EMU membership.

The Commission stressed that its assessment of membership would be positively affected if unemployment were to fall and the fiscal situation stabilized. At the same time, the Commission feared that staying outside EMU might lead to a loss of credibility for the Swedish currency, leading to increased short-term interest rates and a continued large spread between Swedish and EMU long-term interest rates.

When revisiting the issues more than ten years later, some arguments seem to speak more strongly in favor of Swedish membership in EMU, while other arguments speak more strongly against. First, the EMU project must be deemed as a great success. More countries than expected joined in 1999, and although Denmark is not an EMU member, it maintains a fixed exchange rate against the euro, and its monetary policy shadows that of the ECB. The ECB has established credibility for a low inflation policy, and the euro has become a major currency, probably more important than the individual currencies taken together. The gains in terms of economic integration also seem fairly large, perhaps larger than expected in 1996 (see Section 6). Second, since 1996, unemployment has fallen considerably in Sweden (to around $6 \%$ in September 2008), and the fiscal situation has been stabilized (government debt in 2007 was around $40 \%$ of GDP and the government ran a surplus 
of around 3.5\% of GDP). Thus, Sweden today seems less vulnerable to adverse shocks than in 1996. Finally, there do not seem to have been any large country-specific disturbances to the Swedish economy, so the gains from independent monetary policy may have been small. While the last point is not particularly strong, as independent monetary policy may turn out to be of crucial importance in the future, the other arguments suggest that the case for EMU membership may be stronger today than in 1996.

There are however also arguments that speak more strongly against EMU membership today. First, the Commission's fears about a loss in credibility for Swedish monetary policy and the Swedish currency never materialized. As we will see next, Swedish long-term interest rates have converged substantially toward European rates, although not to the same extent as those in the EMU member countries. Second, the recent literature does not find strong support for the proposition that Sweden has lost political influence within the EU (see Section 6). And third, while there was a broad public debate about Swedish EMU membership ahead of the referendum in 2003, public opinion seems to be largely against membership. ${ }^{3}$

All in all, the events of the past ten years help to gain perspective on some of the important issues concerning Swedish membership in EMU that were discussed by the Calmfors Commission. However, at this stage it is not clear whether the case for membership has become stronger or weaker. The remaining Sections will therefore cover many of these issues in more detail.

\section{European business cycles}

In this section I give an overview of the convergence of business cycles in Europe. The purpose is to give a broad view of the similarities of the Swedish and Euro area business cycles, and thus the possible consequences for Sweden of joining the monetary union, and to compare with other European countries that have chosen different strategies in their relationship with the EU and the EMU. I thus compare Swedish data with those of the Euro area as a whole and three groups of countries. The first group contains the four largest Euro area member countries: France, Germany, Italy and Spain. The second group consists of three Nordic countries: Denmark, which is a member of the EU but not of EMU, although it maintains a

\footnotetext{
${ }^{3}$ According to Statistics Sweden, since 2004 around $50 \%$ of the Swedish population have been against EMU membership while 35-40\% have been for membership. However, a more recent poll by SIFO (in October 2008) suggests that the balances may have shifted somewhat in favor of membership, with $47 \%$ against and $42 \%$ for.
} 
fixed exchange rate against the euro within ERM II; Finland, which is a member of EMU; and Norway, which remains outside the EU. Finally, I include in the comparison the United Kingdom, which like Sweden is a member of the EU, but neither of EMU nor ERM II. ${ }^{4}$

To evaluate convergence and the effects of EMU, I compare data from two subsamples: the period before EMU from 1994 to 1998, and the period after the launch of EMU from 1999 to 2007. ${ }^{5}$ The data were collected from various sources; see Appendix A for details.

I study the properties of business cycles in the selected countries in terms of the average level and volatility of a number of business cycle indicators in the different countries and their correlation with the Euro area: GDP growth and the GDP gap (the percent deviation of GDP from trend); the rate of unemployment; the CPI inflation rate; short-term (3-month) and long-term (10-year) interest rates; and the nominal and real exchange rates.

The data are presented in Figures $1-8$, while Tables $1-3$ show sample means, standard deviations and correlations with the Euro area for the two subperiods. The main impression is that there is strong comovement of business cycles across Europe. Most countries experienced an expansion in 1997-2000 with high growth, increasing output gaps, and falling unemployment. This period was followed by a contraction in 2001-2003, with low growth, falling output gaps, and increasing unemployment, but since around 2003, most countries have experienced a gradual expansion of economic activity. At the same time, inflation and interest rates fell dramatically from the early 1990s until around 1999, after which they have been stabilized at low levels. In particular, long-term interest rates have converged strongly since the early 1990s, and in particular after 1999 (with the possible exception of Norway and the UK) ${ }^{6}$ Also Swedish interest rates (short- and long-term) have converged toward the EMU rates, less so than in the EMU member countries and Denmark, but more than in Norway and the UK.

Table 1 shows that most countries have experienced lower average GDP growth, unemployment, and short- and long-term interest rates in the post-EMU period than before 1999, while inflation has been low throughout the sample period. On average Sweden has experienced higher GDP growth, lower unemployment, and

\footnotetext{
${ }^{4}$ The case of the UK is analyzed in detail in the chapter in this volume by DiCecio and Nelson.

${ }^{5}$ I choose 1994 as the starting point for the pre-EMU sample to avoid the turbulent years in the early 1990s in Sweden and many other European countries.

${ }^{6}$ Ehrmann et al. (2007) study in detail the convergence of interest rates within the Euro area.
} 
lower inflation than most Euro area countries in both sample periods. Table 2 shows that Sweden, along with Italy, Spain and the other Nordic countries, have tended to have more volatile business cycles than the three large economies (Germany, France, and the UK), and than the Euro area at large.

As for business cycle correlations, Table 3 shows that the Swedish GDP growth and GDP gap are fairly strongly correlated with its Euro area counterparts, with correlation coefficients above 0.70 after 1999. Although the Swedish business cycle correlation with the Euro area is weaker than those of the largest Euro area members, France, Germany, Italy, and Spain (which often have correlation coefficients around 0.9 ), the business cycle in Sweden seems more strongly correlated with the Euro area than in Norway and the UK, and the correlation is similar to that in Denmark and Finland.

To summarize, European business cycles are closely correlated with each other, and the Swedish business cycle is no exception. Although the large EMU members show even stronger comovement with the Euro area, Sweden tends to be at least as strongly correlated with the Euro area as some EMU members (for instance, Finland), and more closely correlated than Norway and the UK. This evidence suggests that European business cycles are to a large extent driven by common shocks. If this is the case, then membership in EMU would not be very costly for Sweden, and not more so than for some current EMU members. However, before drawing this conclusion, we take a further step by using an estimated model to study the importance of country-specific shocks relative to foreign shocks for the Swedish economy.

\section{The role of country-specific shocks and exchange rate volatility for macroeconomic fluctuations}

The traditional arguments against monetary union rest on two assertions. First, independent monetary policy is helpful to stabilize the economy after country-specific (or "asymmetric") shocks. Such shocks could therefore be costly in a monetary union where the common central bank would not adjust policy sufficiently, as it focuses on stabilizing the union-wide economy. Second, exchange rate movements help to stabilize the economy after shocks. For instance, the economy will recover more easily after a contractionary shock if the exchange rate is allowed to depreciate, something that will not be possible within a monetary union. Both arguments are more important for a small open economy such as Sweden, which would carry a 
small weight within the monetary union and where exchange rate movements have a strong effect on the economy.

The importance of the first argument depends on the prevalence of countryspecific shocks: the more important are these shocks for the domestic economy, the more critical is independent monetary policy. However, the evidence from Section 3 suggests that common shocks may be more important than country-specific shocks for European business cycles. The validity of the second argument rests on the notion that the nominal exchange rate adjusts appropriately after shocks. But exchange rate movements are known not to be very strongly linked to fundamentals (see, for instance, Obstfeld and Rogoff, 2000). If exchange rate movements are driven mainly by idiosyncratic shocks (for instance, to the foreign exchange risk premium), they may induce additional volatility rather than help the economy to adjust after shocks. $^{7}$

In this Section, I try to shed more light on these issues by studying the importance of shocks for the Swedish economy in a model of a small open economy developed and estimated on Swedish data by Adolfson et al. (2007a, 2008). ${ }^{8}$

\subsection{A model of a small open economy}

The model used for these exercises is a Dynamic Stochastic General Equilibrium (DSGE) model with optimizing agents and rational expectations. The model economy consist of four groups of agents: households, firms, the government and the foreign economy. Households maximize utility over an infinite horizon. They consume a basket of domestically produced goods and imported goods, which are supplied by domestic and importing firms, respectively. Households save in domestic and foreign currency-denominated nominal bonds, but must pay a premium on foreign bond holdings, a premium that depends on the domestic economy's net foreign asset position and an idiosyncratic shock. Households also own the capital stock, which they rent to domestic firms, and they decide the rate of capital accumulation given costs of adjusting the rate of investment. Finally, households supply a differentiated labor service under monopolistic competition and staggered wages.

The choice between domestic and foreign bond holdings implies that domestic and foreign interest rates are linked by an uncovered interest rate parity (UIP) condition. However, the premium on foreign bond holdings leads to an exchange rate risk premium that generates short-run deviations from the fundamental value

\footnotetext{
${ }^{7}$ This argument is emphasized by several of the contributions in Jakobsson (2003).

${ }^{8}$ Adolfson et al. (2007b) provide a more detailed non-technical description.
} 
of the exchange rate determined by UIP. Idiosyncratic shocks to this risk premium generate volatility in the exchange rate and therefore inefficient fluctuations in the economy.

There are three types of firms - in the domestic, import, and export sectors that produce differentiated goods under monopolistic competition and set prices in a staggered fashion. Domestic firms either produce consumption or investment goods. Staggered prices on imports and exports imply that exchange rate pass-through to both import and export prices is incomplete in the short run. Thus, changes in the exchange rate do not immediately feed through to import and export prices, but only after a gradual process of price changes.

The government spends resources on consuming part of the domestic good, collects taxes from households, and sets monetary policy. The fiscal surplus/deficit plus the seigniorage are transferred back to the households in a lump sum fashion. Monetary policy is delegated to an independent central bank that sets the interest rate according to a Taylor (1993)-type interest rate rule. In particular, the oneperiod nominal interest rate is set as a function of current and past CPI inflation, the deviation of current and past GDP from trend, and the real exchange rate and the interest rate in the previous quarter. In addition there is a shock to the interest rate rule that captures temporary deviations from the systematic behavior of monetary policy.

Finally, as Sweden is a small open economy, the foreign economy is assumed to be independent of the Swedish economy, so foreign inflation, output, and the foreign interest rate follow an exogenous vector autoregressive (VAR) model. The foreign variables are trade-weighted averages of foreign data.

In total, the model describes the evolution of 27 variables, 15 of which are observable. The model also includes 21 different exogenous disturbances: one is a nonstationary global technology shock common to the domestic and foreign economies, nine shocks are specific to the domestic economy (including a stationary technology shock), three originate in the foreign economy, seven are related to monetary and fiscal policy, and the remaining shock is to the foreign exchange risk premium. The model was is rewritten in terms of stationary variables, log-linearized around its steady state, and then estimated by Adolfson et al. (2007a) on quarterly data from 1980 until the third quarter of 2005, with a structural break in the first quarter of 1993, as Sweden moved from a fixed exchange rate regime to a regime with an inflation target and a flexible exchange rate. I here present results pertaining to the period starting in 1993. 


\subsection{The sources of macroeconomic fluctuations}

To analyze the relative importance of different shocks in the estimated model, I decompose the volatility of key variables - annual domestic and CPI inflation, annual GDP growth, the annualized short-term interest rate, and the real exchange rate - at different horizons into the fraction caused by each shock. I then study these variance decompositions to see $(i)$ what has been the relative importance of domestic shocks for overall volatility; and $(i i)$ what has been the relative importance of exchange rate shocks for volatility in the exchange rate and in the economy at large.

The results are reported in Table $4 .^{9}$ First, panel $(a)$ shows the total forecast error variance (in percentage points) in each variable at different horizons. The dynamics of the model implies that most of the volatility appears after four quarters, and the real exchange rate is more volatile and persistent than the other variables.

Panel $(b)$ reveals that shocks originating in the domestic economy account for much of the variability in domestic variables at all horizons. In the short run, domestic shocks account for 55-95\% of the volatility in CPI inflation, $65-85 \%$ of the volatility in GDP growth, and $35-55 \%$ of the volatility in the short-term interest rate. Also at longer horizons domestic shocks account for most of the volatility of all variables. Shocks originating in the foreign economy in panel $(c)$, on the other hand, account for between 15 and $25 \%$ of the volatility of CPI inflation volatility, GDP growth and the short-term interest rate. Thus, although the analysis in Section 3 suggested the existence of an important common component in the Swedish and Euro area business cycles, the estimated model finds that country-specific shocks are two to three times more important than foreign shocks for Swedish business cycle fluctuations.

There are reasons to be careful when interpreting these results. Justiniano and Preston (2006) argue that models of small open economies such as the one used here are not very successful in capturing the influence of foreign variables. While the common non-stationary technology shock in our model increases the influence of foreign shocks relative to their model, our model still does not seem to capture all comovement of the domestic and foreign economies. For instance, the model implies an unconditional contemporaneous correlation between domestic and foreign output growth of 0.19 , while in the data used to estimate the model this correlation is 0.54 ; the correlation of domestic and foreign inflation is 0.05 in the model and 0.29 in the data; and the interest rate correlation is 0.16 in the model but 0.86 in the

\footnotetext{
${ }^{9}$ The variance decompositions are calculated from impulse responses to each shock. In the calculations I exclude a shock to the inflation target, as this has been constant since 1993.
} 
data. While the inflation correlation in the data is inside a $95 \%$ probability interval around the model correlations, the correlations of output and the interest rate are not. Thus, the model may well overestimate the importance of domestic shocks relative to foreign shocks.

Comparisons with vector autoregressive (VAR) models estimated on Swedish data give mixed support for this view. In a background study for the Calmfors Commission, Jansson (1997) studied the importance of country-specific shocks in an estimated VAR model using data from eleven European countries over the period from 1960 to 1994. He found that country-specific shocks accounted for 75-80\% of fluctuations in Swedish GDP as well as in the GDP deflator, with the remaining 20$25 \%$ being due to common (that is, foreign) shocks. In comparison, country-specific shocks accounted for merely 25-30\% of GDP fluctuations in the core EMU countries (Austria, Belgium, France, Germany, and the Netherlands), but 93\% in Finland and Ireland. This evidence is consistent with the results in panel $(b)$. On the other hand, Lindé (2003) studies a VAR model of the Swedish economy estimated over the more recent period from 1986 to 2002. He reports that foreign shocks account for 45$55 \%$ of fluctuations in Swedish domestic inflation and GDP, in particular at low frequencies. This evidence thus assigns a less important role to country-specific shocks than do the open-economy model and the evidence of Jansson (1997), also suggesting that the open-economy model underestimates the influence of foreign shocks on the Swedish economy.

We now turn to the importance of shocks to the exchange rate. Panel $(d)$ of Table 4 shows that such shocks account for a large fraction of the volatility in the real exchange rate (above $70 \%$ at short horizons), but also $25-45 \%$ of medium-term volatility in CPI inflation (which to some extent is directly determined by exchange rate movements), $15-30 \%$ of GDP growth volatility and $15-20 \%$ of interest rate volatility at medium-term horizons. Thus, exchange rate movements do help to stabilize the economy after disturbances in other sectors, as close to $30 \%$ of the volatility in the real exchange is due to endogenous responses to other shocks. However, the remaining volatility in the exchange rate is due to inefficient fluctuations in the exchange rate risk premium, which act to destabilize the Swedish economy, and these shocks are responsible for a significant portion of Swedish business cycle fluctuations. ${ }^{10}$

\footnotetext{
${ }^{10}$ In their paper in this volume, DiCecio and Nelson argue that shocks to the exchange rate risk premium may be endogenous responses to fundamentals rather than inefficient disturbances. The estimated model used here, however, interprets all such movements as inefficient disturbances to the exchange rate.
} 
The evidence presented here thus gives a mixed view of the costs and benefits of monetary union. On the one hand, the estimated model suggests that countryspecific shocks are an important source of Swedish business cycle fluctuations, and therefore that independent monetary policy is imperative in order to stabilize the economy. (There is reason, though, to suspect that the model overestimates the influence of country-specific shocks.) On the other hand, exchange rate fluctuations are mainly driven by inefficient shocks to the exchange rate risk premium, which are responsible for a large portion of macroeconomic volatility, implying that the benefits of a flexible exchange rate may be small. ${ }^{11}$

\section{What if Sweden had joined EMU in 1999? A counterfac- tual experiment}

A strength of the estimated model is that it is based on the optimizing behavior of private households and firms, and the estimated parameters reflect structural features of the economy, such as preferences and technology, which in principle should be independent of the behavior of monetary and fiscal policy. We can therefore use the model to perform counterfactual policy experiments without being vulnerable to the Lucas (1976) critique. $^{12}$

Thus, in this Section I use the model to evaluate what would have been the consequences if Sweden had joined EMU at the outset in January 1999. The discussion in Section 3 showed that the Swedish economy is fairly well aligned with the Euro area, suggesting that membership in EMU might not have had important consequences for Sweden. On the other hand, the evidence presented in Section 4 showed that country-specific shocks have been the main source of business cycle fluctuations in Sweden since 1993, suggesting that EMU membership might be costly. The counterfactual experiment can help us balance these conflicting views.

\footnotetext{
${ }^{11}$ For the United Kingdom, HM Treasury (2003) reports that most movements in the exchange rate between the British pound and the euro have been stabilizing, that is, movements in response to other shocks. This conclusion is based, first, on the fact that the sterling exchange rate largely has moved in the appropriate direction with respect to the position of the UK business cycle relative to foreign economies, and second, on evidence from an estimated VAR model where exchange rate shocks have a negligible impact on output, prices and interest rates in the UK.

${ }^{12}$ Recently, however, Chari et al. (2008) and Faust (2008) have criticized such a strong structural interpretation of DSGE models.
} 


\subsection{A first impression}

For a first informal impression, Figure 9 shows the monetary policy interest rate, the rate of GDP growth, and the CPI inflation rate in Sweden and the Euro area since 1999. The horizontal lines in panel (c) represent the Riksbank's tolerance band from one to three percent around its two-percent inflation target.

Initially, in 1999 and early 2000, GDP growth was higher and inflation lower in Sweden than in the Euro area, and on balance, monetary policy was slightly more contractionary in Sweden. As inflation and GDP growth picked up in the Euro area, the ECB increased the interest rate more aggressively than the Riksbank in 2000, and kept a more contractionary policy until the end of 2001. The recession that started in 2001 was more long-lived in the Euro area than in Sweden, necessitating a more aggressive monetary expansion by the ECB, with the Riksbank following about a year later when inflation started falling in Sweden. The higher rate of inflation in the Euro area also made the ECB tighten monetary policy earlier and more aggressively in 2006-07. Consequently, monetary policy was more contractionary in Sweden than in the Euro area throughout 2002 and 2003, but more expansionary in 2005-07. In general, the two interest rates have followed similar cycles, but the Euro area interest rate has tended to lead the Swedish interest rate.

Panel (b) shows that although fluctuations in GDP growth have been closely correlated, the GDP growth rate has been higher in Sweden than in the Euro area in almost every quarter since 1999 (with the exception of the 2001 contraction). At the same time, inflation in panel (c) has typically been lower (and more volatile) in Sweden than in the Euro area. In particular, the Swedish CPI inflation rate was below one percent (the lower bound of the Riksbank's tolerance band) in 1999-2000 and in 2004-05.

Due to the uncertain lags in the transmission of monetary policy, it is difficult to say how Swedish membership in EMU from 1999 would have affected the behavior of GDP growth and inflation in Sweden. The ECB's more contractionary monetary policy in 2000-01 might have been appropriate in the boom experienced in Sweden in 2000, and the more expansionary policy in 2002-03 might have dampened the brief downturn in 2003 and increased inflation somewhat in 2004-05, when inflation in Sweden was exceptionally low. However, with slightly longer transmission lags, a more contractionary monetary policy in 2000-01 might have deepened the downturn in 2003, with even lower inflation as a consequence. 


\subsection{Evidence from the estimated model}

To construct a more rigorous counterfactual experiment I use the estimated model to analyze the possible effects of Swedish EMU membership from 1999 until 2005. ${ }^{13}$ In particular, I impose the Euro area short-term interest rate instead of the Swedish interest rate and simulate the model starting from the actual situation in the fourth quarter of 1998, feeding in the estimated historical series of the disturbances (excluding those to monetary policy and the exchange rate). I thus obtain model predictions of what would have been the development of the Swedish economy if the interest rate had followed the ECB interest rate since January 1999. ${ }^{14}$

To impose the ECB interest rate on the model, I follow two different strategies. In the first strategy, I introduce shocks to the estimated monetary policy rule so that the interest rate coincides with the ECB interest rate. This exercise manages to exactly mimic the ECB policy, but it assumes that these deviations from the estimated policy rule are unexpected by private agents, and so it does not capture the effects of systematic monetary policy. That is, private agents expect the Riksbank to follow the estimated Swedish policy rule, but are surprised in every period by the fact that Sweden is in fact a member of EMU.

As an alternative strategy, I instead respecify the monetary policy rule in the model so that it responds also to the rate of nominal exchange rate depreciation and fluctuations in the foreign economy (the current level and three lags of foreign output, inflation and interest rate). I then find the coefficients in this monetary policy rule that best match the behavior of the ECB interest rate since 1999.

Before presenting the results of these two experiments, Figure 10 compares the model predictions of the short-term interest rate, GDP growth, domestic inflation, and CPI inflation with the estimated monetary policy rule. We note that the model tends to underpredict GDP growth in 2001-04, while capturing fairly well the movements in domestic and CPI inflation. ${ }^{15}$

\footnotetext{
${ }^{13}$ The experiment ends in the third quarter of 2005 as this is the last observation used when estimating the model.

${ }^{14}$ If the model had been estimated on Swedish and Euro area data, it would have been natural to simply set the Swedish interest rate equal to the foreign interest rate, implying that the exchange rate would have been fixed (assuming that there were no risk premium shocks). However, the foreign variables in the model represent trade-weighted averages of foreign data, where the Euro area (including Denmark) only represents around $60 \%$. Therefore this strategy is not possible. Furthermore, as the trade-weighted exchange rate would have fluctuated in ways that are difficult to predict even if Sweden had been an EMU member, I do not study the consequences of EMU membership for the exchange rate.

${ }^{15}$ The deviations of GDP growth and inflation from the actual data are due to measurement errors introduced when estimating the model. Without these measurement errors, the model would
} 


\section{Introducing counterfactual monetary policy shocks}

Panels (a) and (b) of Figure 11 show the interest rate when introducing the counterfactual monetary policy shocks in the estimated interest rate rule, and the implied shocks needed to mimic the ECB interest rate. These shocks are not particularly large: their standard deviation is seven basis points, and the largest shock is 14 basis points. For comparison, the standard deviation of monetary policy shocks in the estimated model is ten basis points. Fairly small shocks are thus required to make the Swedish interest rate mimic the ECB interest rate.

Figure 12 shows the predicted development of GDP growth, domestic inflation and CPI inflation with the counterfactual monetary policy shocks. Even if the required shocks are fairly small, the effects are nevertheless reasonably large. With the ECB interest rate, Swedish GDP growth would have been slightly lower in the 2000-01 recession (due to the more contractionary monetary policy), but higher in the period from 2002 to 2003 (after a more expansionary policy). CPI inflation would have been higher in 2000, lower in 2001, and higher in 2002-05. In particular, the ECB policy would have kept Swedish CPI inflation more closely within the Riksbank's tolerance band of one to three percent in 2004 and 2005.

On average, this exercise suggests that EMU membership would have raised Swedish GDP growth by around 0.1 percentage points per year and inflation by around 0.25 percentage points; see panels $(b)$ and $(c)$ of Table 5 . Inflation would also have been less volatile under the ECB policy with no effects on the volatility of GDP growth.

Under this scenario, EMU membership would thus have been unambiguously beneficial for Sweden.

\section{Imposing a counterfactual monetary policy rule}

Panels (c) and (d) of Figure 11 instead show the interest rate obtained with the counterfactual policy rule. In this case it is not possible to perfectly mimic the ECB interest rate, and occasionally there are large deviations of the counterfactual interest rate from the ECB interest rate. Nevertheless, the counterfactual interest rate follows the same cyclical patterns as the ECB interest rate, and, as shown in

have perfectly matched the actual data, as these data were used in the estimation. See Adolfson et al. (2008) for details. Note also that the data for the GDP growth rate in Figure 10 are slightly different from those in Figures 1 and 9. The data in Figure 10 are seasonally adjusted data obtained from Statistics Sweden, while those in the earlier figures are unadjusted data obtained from the OECD. 
Figure 13, it implies the same qualitative effects of EMU relative to the Swedish interest rate: more contractionary monetary policy in 2000-01 and 2004-05 and more expansionary policy in 1999 and 2001-04. Figure 13 shows that the counterfactual rule (which captures the systematic effects of monetary policy) has a stronger effect on the economy than the rule with the counterfactual shocks in Figure 12, and as shown in panel $(d)$ of Table 5 , GDP growth is substantially more volatile with the counterfactual rule. The overall patterns are similar, however. The counterfactual rule model predicts that GDP growth would have been lower than the actual growth rate in 2000 and early 2001, but higher in late 2001 and early 2002 and in late 2003 and early 2004, similar to the model with counterfactual shocks. Also, the counterfactual rule model implies that CPI inflation would have been lower in 2000-01 but higher in 2002-05. Finally, the ECB policy would have kept inflation within the target range in 2004-05, but in this case, inflation would have been far below the lower bound in 2000 .

This counterfactual experiment thus gives a more ambiguous, but largely negative, picture: EMU membership would have increased average GDP growth only marginally (by 0.05 percentage points) but increased its volatility substantially (by around 0.25 percentage points), and the effects on inflation would have been small on average.

\subsection{Going forward}

The model was estimated by Adolfson et al. (2007a) using data only up until the third quarter of 2005, so it cannot make any predictions about the development in more recent years. Nevertheless, going back to Figure 9, we see that inflation in both economies has picked up in 2007, and more recently (in October 2008) reached $4.0 \%$ in Sweden and $3.2 \%$ in the Euro area. At the same time GDP growth has slowed down to $0.9 \%$ in Sweden and $1.4 \%$ in the Euro area in the second quarter of 2008 (according to the OECD). As shown in panel (a), the ECB started increasing its interest rate already in late 2005, and until late 2007, the ECB interest rate was 50 to 75 basis points above the Riksbank rate. Had we been able to continue our experiments through 2007, the model with the ECB interest rate might therefore have predicted lower inflation but also lower GDP growth in Sweden in 2007-08 than has been the case in practice. 


\section{Additional issues}

The estimated model used in the counterfactual experiments was developed to explain the effects of monetary policy on the economy and the interplay between monetary policy and private sector behavior. However, it is largely silent on many other possible consequences of EMU membership. In this Section I therefore briefly discuss some of these issues.

\subsection{Fiscal policy and the Stability and Growth Pact}

Fiscal policy in EMU member countries is constrained by the possibility of sanctions if the rules specified in the Stability and Growth Pact are violated. These rules require government debt to be below $60 \%$ of GDP and the deficit in the government's finances to be below $3 \%$ of GDP. Would these restrictions on fiscal policy have had important implications for Sweden as an EMU member? Probably not. According to Eurostat, Sweden had in 2007 a government surplus of $3.6 \%$ of GDP and a gross debt to GDP ratio of $40.4 \%$. And in the period since 1999, the largest government deficit in Sweden has been 1.2\% of GDP (in 2002) and the largest debt ratio $65.6 \%$ of GDP (in 1999). According to the assessments made by The European Commission, Sweden has therefore always fulfilled the criterion of fiscal sustainability, so the Stability and Growth Pact would likely not have constrained fiscal policy if Sweden had joined EMU in 1999.

\subsection{Economic integration}

An important motivating factor behind the creation of EMU was to enhance economic integration within the European Union and thus increase competition and economic efficiency. Many studies have also tried to measure the impact of EMU on economic integration, such as international trade patterns, financial market integration, and foreign direct investment (FDI).

While the estimated model does take into account the short-run effects of monetary policy on imports and exports, it assumes that the long-run trade shares are constant, and therefore is unable to make any predictions about the effects of EMU membership on long-run trade patterns. Similarly, the counterfactual exercises mimic financial integration by removing the premium on foreign bond holdings for Swedish residents. But financial integration can be expected to happen also in other financial markets. And the model is completely silent on the impact of monetary union on foreign direct investment. 
A large literature has measured the effects of EMU on international trade. Most of these studies have shown that the creation of EMU has increased trade between the member countries, although the exact estimates vary. Micco et al. (2003) estimate that EMU increased trade within the Euro area by 13\% per year between 1999 and 2002. They also find that the introduction of the euro increased trade between members and non-members by an average of $8 \%$ per year. ${ }^{16}$ A more recent study by Flam and Nordström (2007c) finds that intra-Euro area trade has increased by $26 \%$ after the creation of EMU, and trade with non-EMU members by $12 \%$. In a literature survey, Baldwin (2006) concludes that EMU has increased trade between members countries by between 5 and $15 \%$ with a best estimate of $9 \%$, while trade with non-EMU members has increased by around $7 \%{ }^{17}$

There is thus no evidence of trade diversion: most studies show that trade with non-EMU members has also increased as an effect of the introduction of the euro. Swedish trade has therefore already seen increased trade flows due to EMU, and according to Baldwin (2006), the additional gains from EMU membership may be modest. Flam and Nordström (2007b), on the other hand, argue that Swedish trade with the EMU countries would have been 13\% larger in 2002-05 if Sweden had been a member of EMU, implying that the costs of staying outside the monetary union may have been large.

Empirical studies also suggest that financial markets have become more integrated as a consequence of EMU. De Santis (2006) estimates that portfolio flows (in equity and bonds) among Euro area countries increased significantly due to EMU, thus contributing to enhanced regional financial integration and risk-sharing, in addition to the elimination of exchange rate risk. (See also Lane, 2006a; 2006b.) Similarly, Coeurdacier and Martin (2007) argue that EMU significantly reduced transaction costs for equity and bonds inside the Euro area for all investors, but twice as much for investors from EMU member countries than for non-EMU investors. Thus, EMU led to a diversion effect in that EMU countries purchase less equity from non-EMU countries. This evidence suggests that the launch of EMU may have relocated portfolio holdings from Sweden to the EMU member countries, and that Sweden might experience an increase in international portfolio inflows and outflows as a consequence of EMU membership, thus enhancing the efficiency of portfolio diversification.

\footnotetext{
${ }^{16}$ See also the chapter in this volume by Frankel.

${ }^{17}$ Melitz (2005) argues that the effect is probably closer to $15 \%$ than the $9 \%$ favored by Baldwin (2006).
} 
As for foreign direct investment, de Sousa and Lochard (2006) estimate that EMU has stimulated FDI within the Euro area: FDI stocks have increased by around 20\% within EMU, and FDI flows have increased much more. They find no evidence of an investment diversion effect: the UK, Denmark and Sweden have not experienced a fall in FDI inflows, but rather seem to have experienced a positive effect of EMU. In contrast, Flam and Nordström (2007a) do not find any effects of EMU on FDI, but instead argue that the effects on FDI are due to the Single Market. Nevertheless, both studies imply that the gains from Swedish membership in EMU in terms of FDI would be small.

\subsection{Labor markets and wage formation}

Labor mobility could act as an adjustment mechanism in the presence of countryspecific shocks in a monetary union. Compared with for instance the United States, labor mobility is fairly low between European countries. There are many reasons for this, for instance, language and cultural differences, incompatibilities between bureaucracies, and welfare systems (including pension systems). However, labor mobility is low also within European countries, suggesting that other factors are also important.

Unfortunately, data on labor mobility across countries are not readily available. As a proxy, U.S. Department of Labor, Bureau of International Labor Affairs (2002) reports that the average share of movers in the population in the $1990 \mathrm{~s}$ was $7 \%$ in the European Union but $16 \%$ in the U.S. The share also varies considerably across EU countries, from around $2.5 \%$ in Italy to above $15 \%$ in Finland. Likewise, data from the OECD and the U.S. Census Bureau show that the fraction of foreign workers in the total labor force is typically below $10 \%$ in European countries, while it is around $15 \%$ in the U.S. There is some evidence that labor market reforms have become more frequent after the establishment of monetary union, mainly in the direction of deregulation of labor markets (see, for instance, Bertola and Boeri, 2002), although it is unclear whether the reforms were an effect of monetary union (see Duval and Elmeskov, 2005, or the chapter in this volume by Alesina, Ardagna, and Galasso). Nevertheless, it seems unlikely that labor mobility across EMU member states will be sufficient to eliminate the effects of country-specific shocks. Also, it is unlikely that the pace of labor market reform would accelerate significantly as a consequence of Swedish EMU membership.

A second issue related to labor markets regards the effect of monetary union on wage formation. In theory, monetary union may either increase or decrease 
wage restraint. On the one hand, trade unions may internalize the effects of wage demands on inflation and monetary policy to a smaller extent in a monetary union than before, as the effects on union-wide inflation and monetary policy become weaker. This mechanism would imply that wage demands become stronger within a monetary union. (See Soskice and Iversen, 1998, and Cukierman and Lippi, 2001, who build on insights from Calmfors and Driffill, 1988.)

On the other hand, trade unions in a monetary union may take into account the effects of wage demands on their country's competitiveness to a larger extent, as lost competitiveness can not be regained by exchange rate depreciation or devaluation. Therefore wage coordination and restraint may increase, especially in the traded sector. (See Holden, 2003; 2005.)

Posen and Popov Gould (2006) estimate that wage restraint has increased in almost all Euro area members after the launch of EMU. However, wage restraint increased also in Sweden and the UK in the early 1990s, suggesting that the effect may be largely due to the increased credibility of monetary policy, rather than to the creation of EMU per se. Wage restraint is also small throughout the period in Germany, where monetary policy credibility was strong also before EMU. Thus, if wage restraint depends mostly on the credibility of monetary policy, EMU membership would be unlikely to affect wage restraint in Sweden, where Sveriges Riksbank currently enjoys strong credibility for its monetary policy.

\subsection{Political influence}

One possible cost of staying outside EMU, stressed by the Calmfors Commission, could be the potential loss of political influence within the EU. For instance, Euro area finance ministers regularly meet with the Euro Group on the day before meetings of the ECOFIN Council, and outsiders may fear that many important issues may be settled within the Euro Group before the Council meeting.

Recent research casts some light on this issue. Adler-Nissen (2008) conducted interviews with Danish and British EU representatives. She reports that many Danish representatives felt that being outside EMU constrained their possibilities to advance Danish interests within the EU, and that various strategies were needed to compensate for this constraint. Other studies instead suggest that being outside EMU is not a decisive disadvantage within the European Council. Lindahl and Naurin (2003) and Naurin (2007) conducted interviews with working group representatives in the European Council to study the cooperation patterns within the EU. Their results show that the most popular cooperation partners were Germany, France, and the 
UK, with Sweden, the Netherlands, and Denmark following closely, in spite of their small weights in the final voting procedures. Similarly, Tallberg (2008) reports evidence on the EU bargaining power based on interviews with present and former heads of government and top officials. He reports that, again, Germany, France and the UK exert the greatest influence in Council negotiations. When asked directly, $79 \%$ of the respondents in the study by Lindahl and Naurin (2003) replied that different countries' decision to join or stay outside EMU does not matter at all for the cooperation pattern. Consequently, while this is not a settled issue, the available evidence suggests that there are no strong political disadvantages for Sweden of remaining outside EMU.

\section{$7 \quad$ Final remarks}

After the referendum in 2003 and the strong rejection of the euro, the question of Swedish membership in EMU disappeared from the political agenda. The major political parties agreed that at least two parliamentary elections would be needed before the issue could be taken up for serious consideration again. Thus, EMU membership is not likely to appear on the agenda until after the elections of September 2010 .

Ten years after the launch of EMU, the present paper nevertheless offers an analysis of the pros and cons of Swedish membership. The evidence presented here is not conclusive about whether participation in EMU would be beneficial or costly for the Swedish economy. The analysis also suggests that the consequences of Swedish membership in EMU since the launch in 1999 would not have been dramatic. To some extent, this result probably reflects the fact that the last ten years have been a relatively calm period for the world economy, without any large disturbances to the Swedish nor to the Euro area economy. At least this was the case until mid-2007. The outcome of the current financial crisis could lead to sharper conclusions about the potential costs and benefits of EMU.

The crisis could also have effects on public opinion in Sweden vis-à-vis the monetary union. There is no doubt that the Swedish decision in 1994 to become a member of the European Union was influenced by the deep recession in the early 1990s, coupled with a banking crisis and the European exchange rate crisis in 1992-93. Sweden goes into the current crisis in a strong position, with low unemployment and solid government finances. If the Swedish economy were to suffer strong adverse effects of the crisis in spite of its apparent strength, then public opinion may well shift and 
participation in EMU could become reality sooner than expected. If, on the other hand, Sweden were to come out well from the crisis relative to the Euro area, then Swedish participation in the monetary union might be postponed for a long time. In any case, the present study could be used as a starting point for a renewed debate on possible membership in the third stage of the Economic and Monetary Union. 


\section{A Data definitions and sources}

GDP: Gross domestic product, constant prices, 2000=100. Source: OECD.

Unemployment: Standardized unemployment rate, all persons, seasonally adjusted, per cent. Source: OECD.

Consumer prices: Euro area: Harmonized index of consumer prices, all items, $2000=100$. Other countries: Consumer price index, all items, $2000=100$. Source: OECD.

Short-term interest rate: Euro area: 3-month EURIBOR; Sweden: 90-day treasury bill yield; France: 3-month PIBOR; Germany: 3-month FIBOR; Italy: 3-month interbank deposit rate; Spain: 3-month interbank loan rate; Denmark: 3-month uncollateralized interbank rate; Finland: 3-month HELIBOR; Norway: 3-month NIBOR; UK: 3-month mean LIBID/LIBOR. All rates per cent per annum. Source: OECD.

Long-term interest rate: 10-year government bond yield, per cent per annum. Source: OECD.

Nominal exchange rate: Noon buying rates in New York City for cable transfers payable in foreign currencies, quarterly averages of daily data. Source: Federal Reserve Bank of St. Louis.

Real exchange rate: Nominal exchange rate deflated by consumer price index, $1999=100$.

Monetary policy rate: Quarterly averages of daily data. Source: European Central Bank, Sveriges Riksbank. 


\section{References}

Adler-Nissen, Rebecca (2008), "The diplomacy of opting out: A Bourdieudian approach to national integration strategies," Journal of Common Market Studies, $46(3), 663-684$.

Adolfson, Malin, Michael K. Andersson, Stefan Laséen, Jesper Lindé, and Anders Vredin (2007a), "Modern forecasting models in action: Improving macroeconomic analyses at central banks," International Journal of Central Banking, 3 (4), 111144.

Adolfson, Malin, Stefan Laséen, Jesper Lindé, and Mattias Villani (2007b), "RAMSES - A new general equilibrium model for monetary policy analysis," Sveriges Riksbank Economic Review, 2, 5-39.

(2008), "Evaluating an estimated New Keynesian small open economy model," Journal of Economic Dynamics and Control, 32 (8), 2690-2721.

Baldwin, Richard (2006), In or Out: Does It Matter? An Evidence-Based Analysis of the Euro's Trade Effects, Centre for Economic Policy Research.

Bertola, Giuseppe and Tito Boeri (2002), "EMU labour markets two years on: Microeconomics tensions and institutional evolution," in Marco Buti and André Sapir (eds.), EMU and Economic Policy in Europe: The Challenge of the Early Years, Edward Elgar.

Calmfors, Lars and John Driffill (1988), "Bargaining structure, corporatism, and macroeconomic performance," Economic Policy, 3 (6), 13-61.

Calmfors, Lars, Harry Flam, Nils Gottfries, Magnus Jerneck, Rutger Lindahl, Janne Haaland Matlary, Ewa Rabinowicz, Anders Vredin, and Christina Nordh Berntsson (1996), Sverige och EMU, SOU 1996:158, EMU-utredningen. Published in English as EMU: A Swedish Perspective, Kluwer Academic Publishers, 1997.

Chari, V.V., Patrick J. Kehoe, and Ellen R. McGrattan (2008), "New Keynesian models: Not yet useful for policy analysis," Research Department Staff Report No. 409, Federal Reserve Bank of Minneapolis.

Coeurdacier, Nicolas and Philippe Martin (2007), "The geography of asset trade and the Euro: Insiders and outsiders," Discussion Paper No. 6032, Centre for Economic Policy Research. Forthcoming, Journal of the Japanese and International Economies.

Cukierman, Alex and Francesco Lippi (2001), "Labour markets and monetary union: A strategic analysis," Economic Journal, 111 (473), 541-565.

De Santis, Roberto A. (2006), "The geography of international portfolio flows, international CAPM and the role of monetary policy frameworks," Working Paper No. 678, European Central Bank. 
de Sousa, José and Julie Lochard (2006), "Does the single currency affect FDI? A gravity-like approach," Manuscript, University of Paris 1-Panthéon-Sorbonne.

Duval, Romain and Jørgen Elmeskov (2005), "The effects of EMU on structural reforms in labour and product markets," Working Paper No. 438, Economics Department, OECD.

Ehrmann, Michael, Marcel Fratzscher, Refet S. Gürkaynak, and Eric T. Swanson (2007), "Convergence and anchoring of yield curves in the Euro area," Working Paper No. 817, European Central Bank.

Faust, Jon (2008), "DSGE models in a second-best world of policy analysis," Manuscript, Johns Hopkins University.

Flam, Harry and Håkan Nordström (2007a), "The euro and Single Market impact on trade and FDI," Manuscript, Institute for International Economic Studies, Stockholm University.

(2007b), "Euron och utrikeshandeln: Hur mycket handel förlorar Sverige årligen?" Ekonomisk debatt, 35 (5), 16-30.

(2007c), "Explaining large euro effects on trade: The extensive margin and vertical specialization," Manuscript, Institute for International Economic Studies, Stockholm University.

Gottfries, Nils (1996), "Reservation (Statement of dissenting opinion)," in Calmfors et al. (1996).

HM Treasury (2003), "The exchange rate and macroeconomic adjustment," EMU Study.

Holden, Steinar (2003), "Wage-setting under different monetary regimes," Economica, 70 (278), 251-265.

- (2005), "Monetary regimes and the coordination of wage setting," European Economic Review, 49 (4), 833-843.

Jakobsson, Ulf (ed.) (2003), Därför euron. Tio ekonomer om den gemensamma valutan, Ekerlids, Stockholm.

Jansson, Per (1997), "How large is the risk of asymmetric shocks for Sweden?" Swedish Economic Policy Review, 4 (2), 447-486.

Justiniano, Alejandro and Bruce Preston (2006), "Can structural small open economy models account for the influence of foreign disturbances?" Manuscript, Columbia University.

Lane, Philip R. (2006a), "Global bond portfolios and EMU," International Journal of Central Banking, 2 (2), 1-23. 
(2006b), "The real effects of European monetary union," Journal of Economic Perspectives, 20 (4), 47-66.

Lindahl, Rutger and Daniel Naurin (2003), "Gemenskap, utanförskap och inflytande i EU:s ministerråd," Working Paper No. 03/2, Centrum för Europaforskning vid Göteborgs universitet (CERGU).

Lindé, Jesper (2003), "Monetary policy shocks and business cycle fluctuations in a small open economy: Sweden 1986-2002," Working Paper No. 153, Sveriges Riksbank.

Lucas, Robert E. (1976), "Econometric policy evaluation: A critique," CarnegieRochester Conference Series on Public Policy, 1, 19-46.

Melitz, Jacques (2005), "Comments on Richard Baldwin, 'The euro's trade effects'," ECB conference on "What effects is EMU having on the euro area and its member countries?", Frankfurt, 16-17 June.

Micco, Alejandro, Ernesto Stein, and Guillermo Ordoñez (2003), "The currency union effect on trade: Early evidence from EMU," in Richard Baldwin, Giuseppe Bertola, and Paul Seabright (eds.), EMU: Assessing the Impact of the Euro, Blackwell Publishing. Also published in Economic Policy, 18 (37), 2003, 315-356.

Naurin, Daniel (2007), "Network capital and cooperation patterns in the working groups of the council of the EU," Working Paper No. 2007/14, Robert Schumann Center for Advanced Studies, European University Institute.

Obstfeld, Maurice and Kenneth Rogoff (2000), "The six major puzzles in international macroeconomics: Is there a common cause?" in Ben S. Bernanke and Kenneth Rogoff (eds.), NBER Macroeconomics Annual, The MIT Press.

Posen, Adam S. and Daniel Popov Gould (2006), "Has EMU had any impact on the degree of wage restraint?" Working Paper No. 06-6, Institute for International Economics.

Soskice, David and Torben Iversen (1998), "Multiple wage-bargaining systems in the single European currency area," Oxford Review of Economic Policy, 14 (3), $110-124$.

Tallberg, Jonas (2008), "Bargaining power in the European Council," Journal of Common Market Studies, 46 (3), 685-708.

Taylor, John B. (1993), "Discretion versus policy rules in practice," CarnegieRochester Conference Series on Public Policy, 39, 195-214.

U.S. Department of Labor, Bureau of International Labor Affairs (2002), "Labor market in the 21st century: Skills and mobility," Proceedings of a Joint United States and European Union Conference. 
Table 1: Sample mean of selected business cycle indicators

\begin{tabular}{|c|c|c|c|c|c|c|c|c|c|c|}
\hline Sample & $\begin{array}{l}\text { Euro } \\
\text { area }\end{array}$ & Sweden & France & Germany & Italy & Spain & Denmark & Finland & Norway & UK \\
\hline \multicolumn{11}{|c|}{ (a) GDP growth } \\
\hline $1994-1998$ & $2.2^{a}$ & 3.1 & 2.2 & 1.8 & 1.8 & $3.4^{a}$ & 3.2 & 4.3 & 4.1 & 3.2 \\
\hline 1999-2007 & 2.1 & 3.1 & 2.1 & 1.5 & $1.4^{b}$ & 3.6 & 2.0 & 3.3 & 2.3 & 2.7 \\
\hline \multicolumn{11}{|c|}{ (b) Unemployment } \\
\hline $1994-1998$ & 10.4 & 9.2 & 11.3 & 8.7 & 11.1 & 17.5 & 6.2 & 14.2 & 4.7 & 7.7 \\
\hline 1999-2007 & 8.4 & 6.0 & 9.0 & 8.8 & $8.5^{b}$ & 10.3 & 4.7 & 8.8 & 3.8 & $5.1^{b}$ \\
\hline \multicolumn{11}{|c|}{ (c) CPI inflation rate } \\
\hline $1994-1998$ & 2.1 & 1.1 & 1.4 & 1.7 & 3.3 & 3.2 & 2.0 & 1.0 & 1.9 & 2.1 \\
\hline 1999-2007 & 2.0 & 1.3 & 1.6 & 1.5 & 2.2 & 3.0 & 2.1 & 1.5 & 1.9 & 1.5 \\
\hline \multicolumn{11}{|c|}{ (d) Short-term interest rate } \\
\hline $1994-1998$ & 5.4 & 6.0 & 4.7 & 4.0 & 7.9 & 6.9 & 4.8 & 4.3 & 5.1 & 6.5 \\
\hline 1999-2007 & 3.2 & 3.1 & & & & & 3.4 & & 4.9 & 4.9 \\
\hline \multicolumn{11}{|c|}{ (e) Long-term interest rate } \\
\hline $1994-1998$ & 7.0 & 7.9 & 6.3 & 6.0 & 8.8 & 8.2 & 6.9 & 7.1 & 6.6 & 7.3 \\
\hline 1999-2007 & 4.4 & 4.6 & 4.4 & 4.3 & 4.6 & 4.4 & 4.5 & 4.4 & 5.2 & 4.8 \\
\hline
\end{tabular}

Note: Quarterly data, 1994:1-2007:4, except ${ }^{a} 1996: 1-1998: 4,{ }^{b} 1999: 1-2007: 3$. 
Table 2: Standard deviation of selected business cycle indicators

\begin{tabular}{|c|c|c|c|c|c|c|c|c|c|c|}
\hline Sample & $\begin{array}{c}\text { Euro } \\
\text { area }\end{array}$ & Sweden & France & Germany & Italy & Spain & Denmark & Finland & Norway & UK \\
\hline \multicolumn{11}{|c|}{ (a) GDP growth } \\
\hline $1994-1998$ & $0.73^{a}$ & 1.18 & 1.01 & 0.82 & 1.22 & $0.95^{a}$ & 1.75 & 1.22 & 1.89 & 0.64 \\
\hline 1999-2007 & 1.04 & 1.16 & 0.99 & 1.39 & $1.24^{c}$ & 0.72 & 1.50 & 1.28 & 1.38 & 0.64 \\
\hline \multicolumn{11}{|c|}{ (b) GDP gap } \\
\hline $1994-1998$ & $0.54^{b}$ & 0.87 & 0.59 & 0.55 & 0.77 & $0.72^{b}$ & 0.88 & 1.07 & 1.17 & 0.34 \\
\hline 1999-2007 & 0.76 & 0.81 & 0.71 & 1.04 & $0.85^{c}$ & 0.52 & 1.12 & 1.05 & 0.83 & 0.42 \\
\hline \multicolumn{11}{|c|}{ (c) Unemployment } \\
\hline $1994-1998$ & 0.25 & 0.72 & 0.30 & 0.55 & 0.31 & 1.63 & 1.09 & 2.01 & 1.05 & 1.20 \\
\hline $1999-2007$ & 0.55 & 0.88 & 0.63 & 1.05 & $1.44^{c}$ & 1.37 & 0.66 & 0.98 & 0.68 & $0.38^{c}$ \\
\hline \multicolumn{11}{|c|}{ (d) CPI inflation rate } \\
\hline $1994-1998$ & 0.61 & 1.17 & 0.53 & 0.64 & 1.28 & 1.23 & 0.22 & 0.59 & 0.63 & 0.45 \\
\hline 1999-2007 & 0.43 & 0.87 & 0.51 & 0.55 & 0.41 & 0.59 & 0.56 & 0.95 & 1.12 & 0.55 \\
\hline \multicolumn{11}{|c|}{ (e) Short-term interest rate } \\
\hline $1994-1998$ & 1.19 & 1.96 & 1.36 & 0.87 & 2.00 & 1.94 & 1.16 & 1.10 & 1.16 & 0.74 \\
\hline 1999-2007 & 0.94 & 0.87 & & & & & 1.07 & & 2.07 & 0.84 \\
\hline \multicolumn{11}{|c|}{ (f) Long-term interest rate } \\
\hline $1994-1998$ & 1.59 & 2.15 & 1.18 & 0.95 & 2.81 & 2.52 & 1.31 & 1.86 & 1.00 & 1.11 \\
\hline 1999-2007 & 0.65 & 0.74 & 0.64 & 0.61 & 0.65 & 0.70 & 0.72 & 0.70 & 0.98 & 0.38 \\
\hline \multicolumn{11}{|c|}{ (g) Nominal exchange rate ${ }^{d}$} \\
\hline 1994-1998 & & 4.52 & 1.52 & 2.56 & 4.14 & 2.53 & 1.93 & 3.63 & 2.71 & 9.43 \\
\hline 1999-2007 & & 3.27 & & & & & 0.15 & & 3.42 & 4.89 \\
\hline \multicolumn{11}{|c|}{ (h) Real exchange rate } \\
\hline $1994-1998$ & & 4.09 & 1.89 & 2.80 & 4.83 & 1.97 & 1.65 & 3.24 & 2.33 & 9.75 \\
\hline 1999-2007 & & 4.90 & 0.94 & 1.58 & 0.55 & 2.56 & 0.86 & 2.43 & 3.85 & 6.34 \\
\hline
\end{tabular}

Note: Quarterly data, 1994:1-2007:4, except ${ }^{a} 1996: 1-1998: 4,{ }^{b} 1995: 1-1998: 4,{ }^{c} 1999: 1-2007: 3$. ${ }^{d} 1999=100$. 
Table 3: Correlation coefficient of selected business cycle indicators with Euro area counterpart

\begin{tabular}{|c|c|c|c|c|c|c|c|c|c|}
\hline Sample & Sweden & France & Germany & Italy & Spain & Denmark & Finland & Norway & $\mathrm{UK}$ \\
\hline \multicolumn{10}{|c|}{ (a) GDP growth } \\
\hline $1996-1998$ & 0.77 & 0.84 & 0.80 & 0.73 & 0.88 & -0.02 & 0.79 & -0.09 & 0.80 \\
\hline 1999-2007 & 0.70 & 0.89 & 0.93 & $0.93^{a}$ & 0.89 & 0.70 & 0.85 & 0.50 & 0.71 \\
\hline \multicolumn{10}{|c|}{ (b) GDP gap } \\
\hline $1995-1998$ & 0.84 & 0.80 & 0.76 & 0.79 & 0.91 & 0.19 & -0.31 & -0.19 & 0.78 \\
\hline $1999-2007$ & 0.74 & 0.89 & 0.95 & $0.92^{a}$ & 0.93 & 0.73 & 0.84 & 0.52 & 0.66 \\
\hline \multicolumn{10}{|c|}{ (c) Unemployment } \\
\hline $1994-1998$ & 0.86 & 0.80 & -0.15 & -0.50 & 0.78 & 0.61 & 0.73 & 0.69 & 0.67 \\
\hline 1999-2007 & 0.50 & 0.87 & 0.47 & $0.47^{a}$ & 0.58 & 0.74 & 0.63 & 0.58 & $0.07^{a}$ \\
\hline \multicolumn{10}{|c|}{ (d) CPI inflation rate } \\
\hline $1994-1998$ & 0.79 & 0.85 & 0.75 & 0.84 & 0.96 & 0.18 & -0.29 & -0.48 & 0.64 \\
\hline 1999-2007 & 0.52 & 0.85 & 0.80 & 0.65 & 0.75 & 0.01 & 0.25 & 0.10 & 0.09 \\
\hline \multicolumn{10}{|c|}{ (e) Short-term interest rate } \\
\hline $1994-1998$ & 0.95 & 0.96 & 0.81 & 0.86 & 0.94 & 0.89 & 0.92 & 0.24 & -0.53 \\
\hline 1999-2007 & 0.79 & & & & & 0.99 & & 0.73 & 0.67 \\
\hline \multicolumn{10}{|c|}{ (f) Long-term interest rate } \\
\hline $1994-1998$ & 0.99 & 0.99 & 0.98 & 0.99 & 0.99 & 0.99 & 0.97 & 0.93 & 0.94 \\
\hline 1999-2007 & 0.94 & 1.00 & 1.00 & 1.00 & 1.00 & 0.99 & 1.00 & 0.93 & 0.83 \\
\hline
\end{tabular}

Note: Quarterly data, 1994:1-2007:4, except ${ }^{a}$ 1999:1-2007:3. 
Table 4: Variance decomposition in estimated model

\begin{tabular}{|c|c|c|c|c|c|}
\hline Horizon (quarters) & $\begin{array}{c}\text { Domestic } \\
\text { inflation }\end{array}$ & $\begin{array}{c}\text { CPI } \\
\text { inflation }\end{array}$ & $\begin{array}{c}\text { GDP } \\
\text { growth rate }\end{array}$ & $\begin{array}{l}\text { Short-term } \\
\text { interest rate }\end{array}$ & $\begin{array}{c}\text { Real } \\
\text { exchange rate }\end{array}$ \\
\hline \multicolumn{6}{|l|}{ (a) Variance } \\
\hline 1 & 0.71 & 0.51 & 0.48 & 0.23 & 5.52 \\
\hline 4 & 1.00 & 0.89 & 0.97 & 0.25 & 23.57 \\
\hline 20 & 0.02 & 0.11 & 0.08 & 0.05 & 3.23 \\
\hline 40 & 0.01 & 0.02 & 0.01 & 0.02 & 0.61 \\
\hline \multicolumn{6}{|c|}{ (b) Fraction due to domestic shocks } \\
\hline 1 & 99.4 & 95.2 & 83.5 & 35.0 & 19.6 \\
\hline 4 & 90.6 & 54.6 & 66.2 & 53.7 & 15.2 \\
\hline 20 & 35.8 & 32.0 & 45.8 & 66.2 & 74.1 \\
\hline 40 & 68.3 & 71.2 & 59.4 & 71.1 & 73.3 \\
\hline \multicolumn{6}{|c|}{ (c) Fraction due to foreign shocks } \\
\hline 1 & 0.3 & 1.3 & 5.0 & 0.9 & 3.7 \\
\hline 4 & 4.9 & 15.6 & 17.2 & 16.1 & 11.2 \\
\hline 20 & 29.3 & 23.9 & 19.1 & 18.1 & 1.1 \\
\hline 40 & 30.2 & 8.8 & 9.3 & 28.2 & 22.2 \\
\hline \multicolumn{6}{|c|}{ (d) Fraction due to exchange rate shock } \\
\hline 1 & 0.3 & 2.8 & 1.4 & 1.8 & 75.4 \\
\hline 4 & 3.9 & 27.0 & 12.3 & 21.2 & 71.7 \\
\hline 20 & 34.0 & 43.1 & 31.9 & 15.6 & 24.6 \\
\hline 40 & 0.0 & 19.0 & 29.7 & 0.1 & 4.0 \\
\hline \multicolumn{6}{|c|}{ (e) Fraction due to policy shocks } \\
\hline 1 & 0.0 & 0.7 & 10.2 & 62.4 & 1.3 \\
\hline 4 & 0.6 & 2.8 & 4.4 & 9.0 & 1.9 \\
\hline 20 & 0.9 & 0.9 & 3.2 & 0.1 & 0.2 \\
\hline 40 & 1.5 & 1.0 & 1.6 & 0.7 & 0.4 \\
\hline
\end{tabular}

This table reports the forecast error variance of key variables (in percentage points) in the estimated model at different horizons and the fraction of this variance (in percent) that is due to different sets of shocks. The GDP growth rate and the inflation rates are four-quarter rates, all data are expressed as percent per annum. The shock to the time-varying inflation target was excluded from the calculations; the policy shocks include shocks to monetary policy (to the interest rate rule) and to fiscal policy (to tax rates and government expenditure). 
Table 5: Properties of actual data and simulated model data, 1999-2005

\begin{tabular}{|c|c|c|c|c|}
\hline Horizon (years) & $\begin{array}{l}\text { Short-term } \\
\text { interest rate }\end{array}$ & $\begin{array}{c}\text { GDP } \\
\text { growth rate }\end{array}$ & $\begin{array}{l}\text { Domestic } \\
\text { inflation }\end{array}$ & $\begin{array}{c}\text { CPI } \\
\text { inflation }\end{array}$ \\
\hline \multicolumn{5}{|l|}{ (a) Data } \\
\hline Mean & 3.18 & 2.61 & 1.46 & 1.53 \\
\hline Standard deviation & 0.83 & 1.26 & 0.59 & 0.95 \\
\hline \multicolumn{5}{|l|}{ (b) Estimated model } \\
\hline Mean & 3.18 & 2.17 & 1.39 & 1.55 \\
\hline Standard deviation & 0.83 & 1.42 & 0.60 & 0.97 \\
\hline \multicolumn{5}{|c|}{ (c) Model with counterfactual monetary policy shocks } \\
\hline Mean & 2.96 & 2.28 & 1.56 & 1.79 \\
\hline Standard deviation & 0.95 & 1.41 & 0.50 & 0.82 \\
\hline \multicolumn{5}{|c|}{ (d) Model with counterfactual monetary policy rule } \\
\hline Mean & 2.96 & 2.23 & 1.96 & 1.56 \\
\hline Standard deviation & 0.97 & 1.68 & 0.68 & 0.92 \\
\hline
\end{tabular}


Figure 1: Annual GDP growth rate in the Euro area and selected European economies, 1990-2007

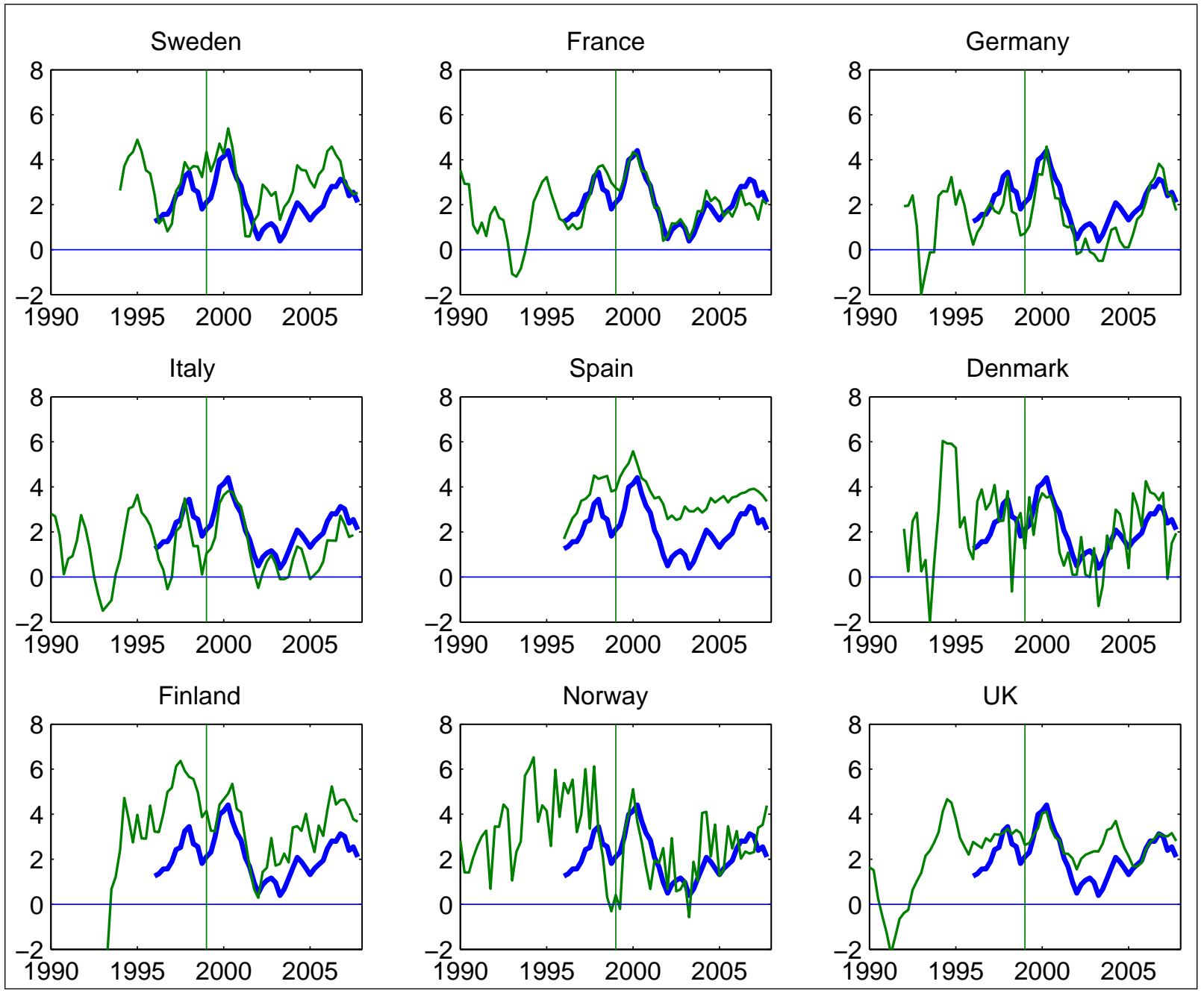

Note: Four-quarter GDP growth rate in Euro area (thick line) and selected European countries (thin line). Percent per annum. The vertical line represents the launch of EMU in January 1999. Source: OECD. 
Figure 2: GDP gap in the Euro area and selected European economies, 1990-2007

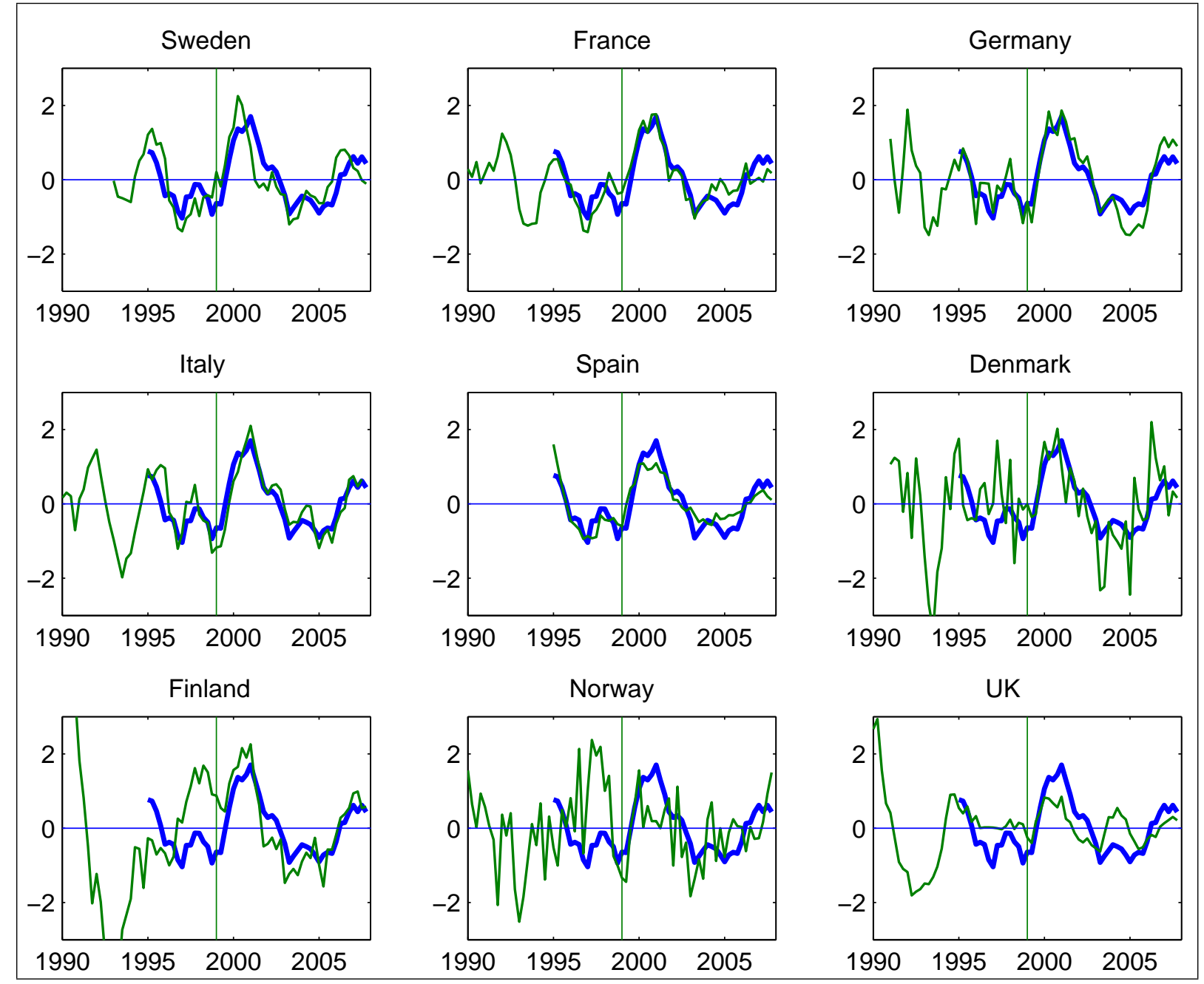

Note: Percent deviation of GDP from trend in Euro area (thick line) and selected European countries (thin line). The trend was calculated by the author using the Hodrick-Prescott filter over the entire sample and a smoothing parameter of 1,600. The vertical line represents the launch of EMU in January 1999. Source: OECD. 
Figure 3: Unemployment rate in the Euro area and selected European economies, 1990-2007

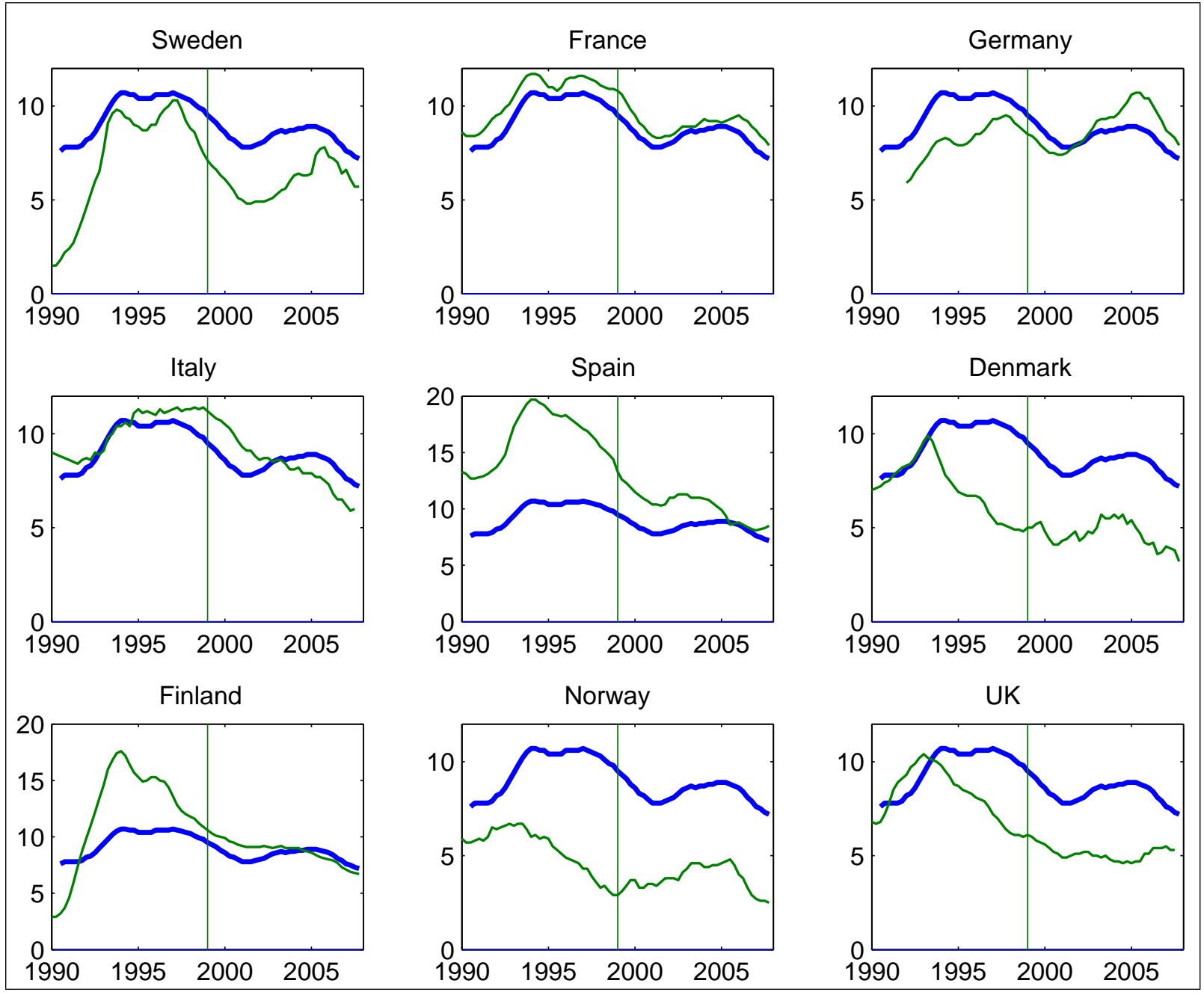

Note: Standardized unemployment rate in Euro area (thick line) and selected European countries (thin line). Percent. The vertical line represents the launch of EMU in January 1999. Source: OECD. 
Figure 4: CPI inflation rate in the Euro area and selected European economies, $1990-2007$

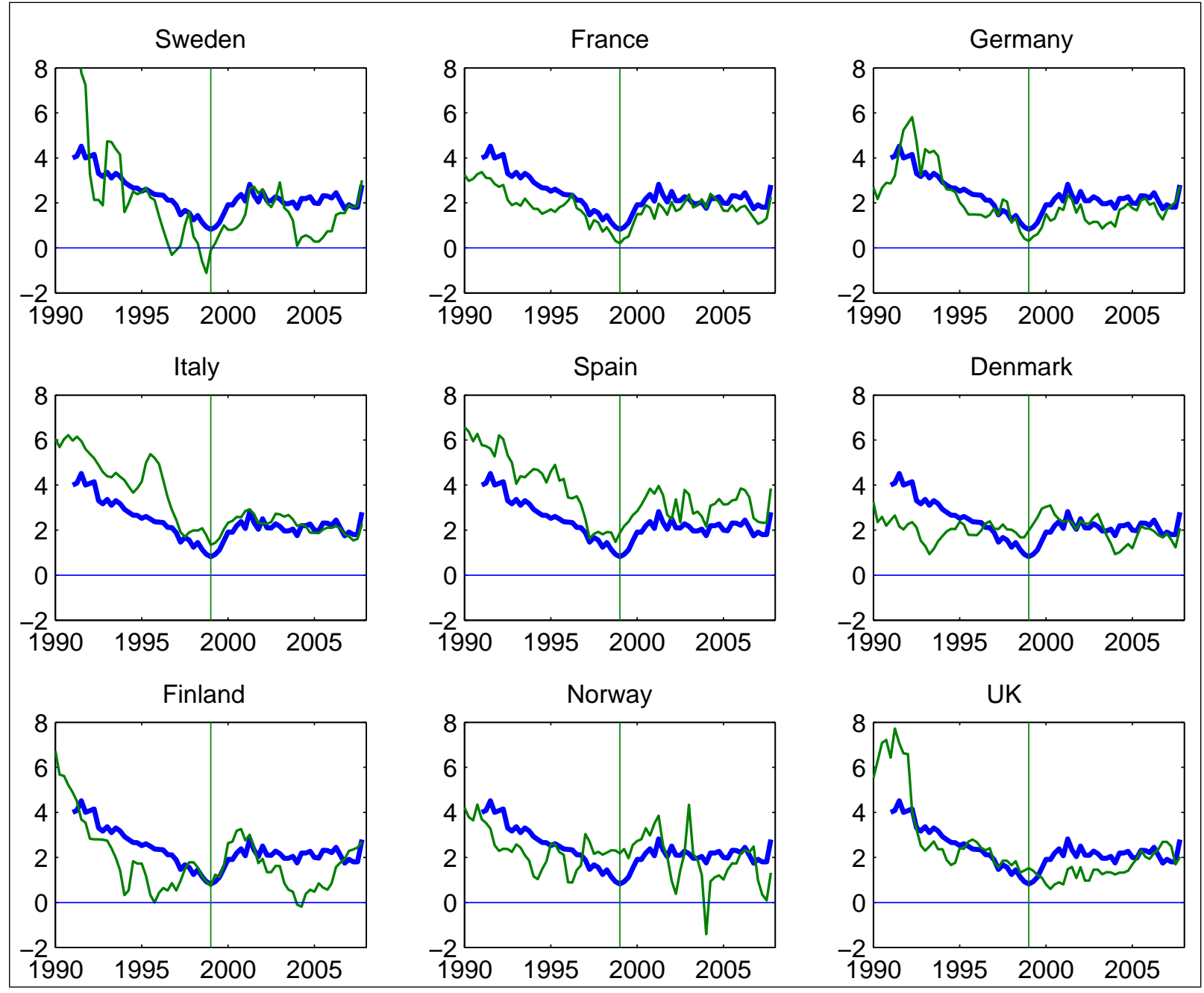

Note: Four-quarter CPI inflation rates in Euro area (thick line) and selected European countries (thin line). Quarterly averages of monthly data, percent per annum. The vertical line represents the launch of EMU in January 1999. Source: OECD. 
Figure 5: Short-term interest rate in the Euro area and selected European economies, 1990-2007

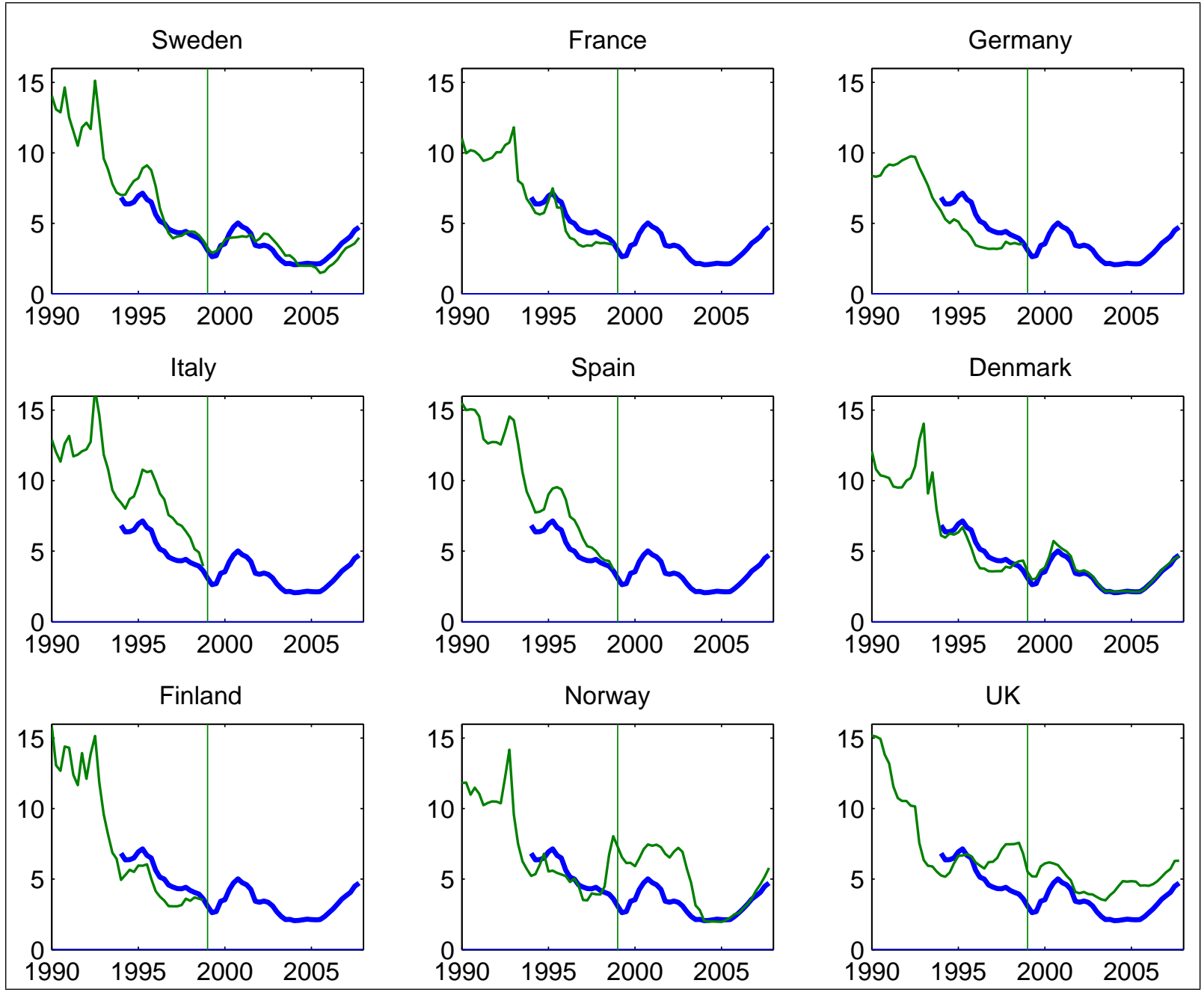

Note: 3-month interest rates in Euro area (thick line) and selected European countries (thin line). Quarterly averages, percent per annum. The vertical line represents the launch of EMU in January 1999. Source: OECD. 
Figure 6: Long-term interest rate in the Euro area and selected European economies, 1990-2007

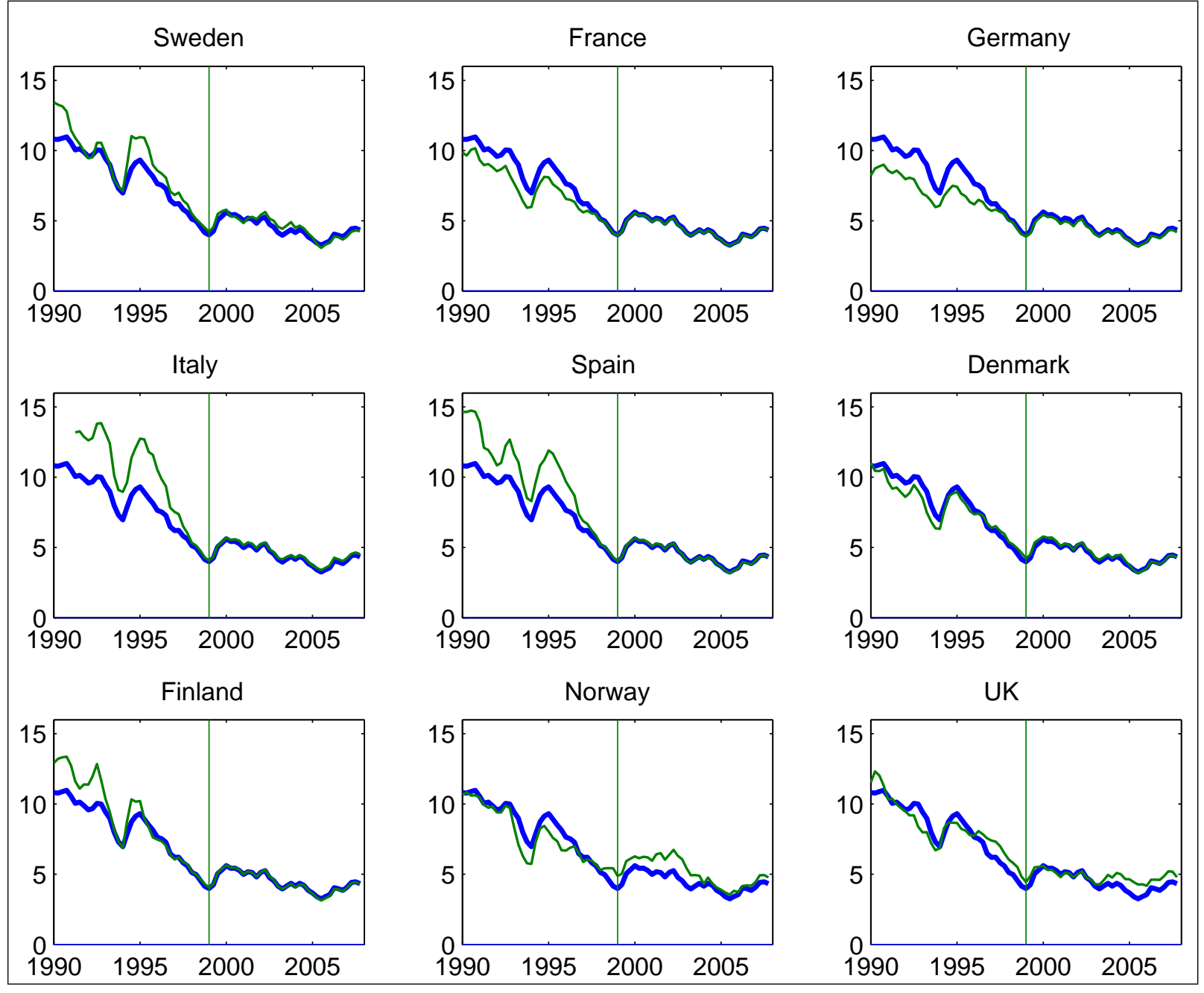

Note: 10-year government bond yield in Euro area (thick line) and selected European countries (thin line). Quarterly averages, percent per annum. The vertical line represents the launch of EMU in January 1999. Source: OECD. 
Figure 7: Nominal exchange rate against the ECU/Euro in selected European economies, 1990-2007

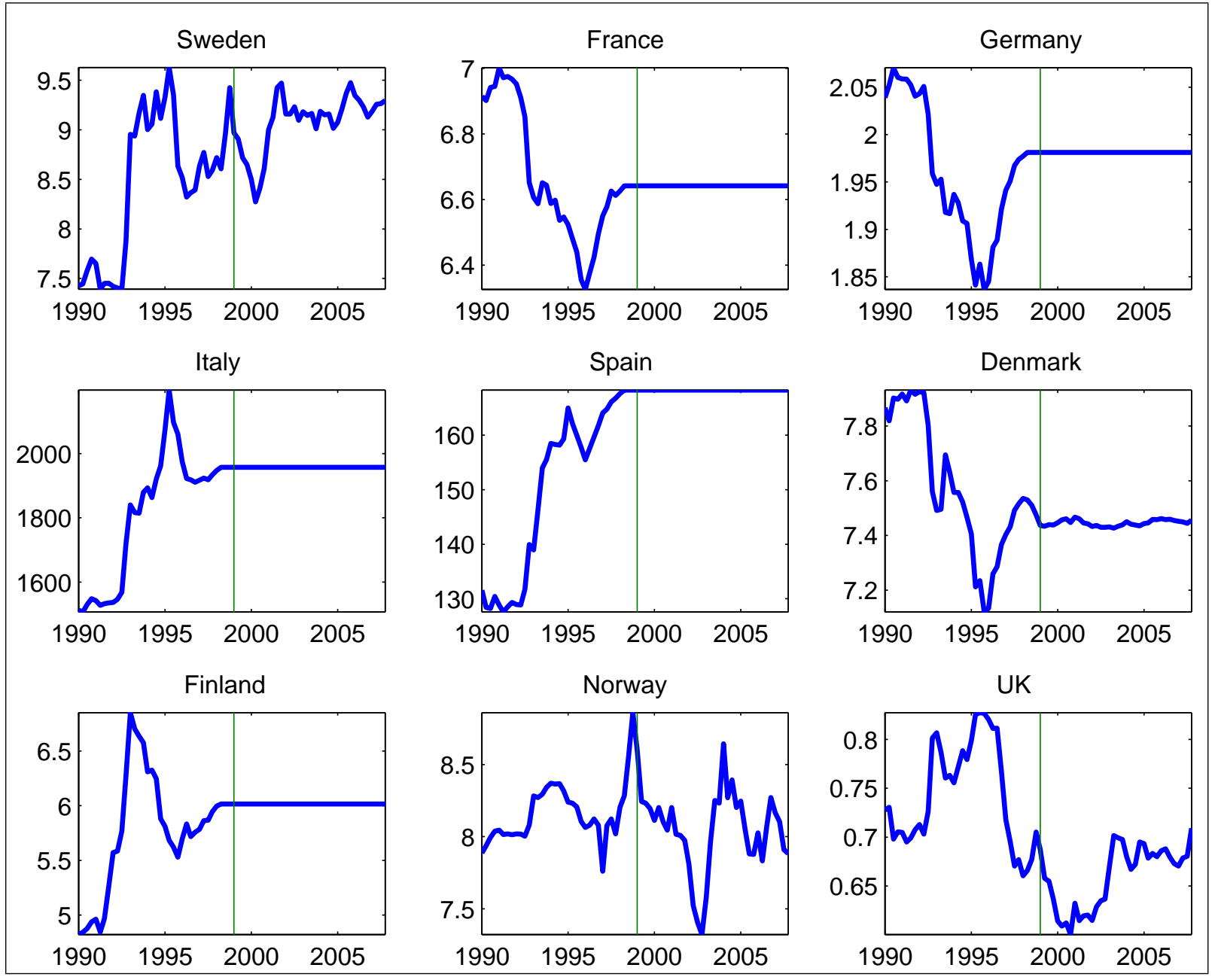

Note: Domestic currency price of ECU/Euro. Quarterly averages of daily data. The vertical line represents the launch of EMU in January 1999. Source: FRED data base, Federal Reserve Bank of St. Louis. 
Figure 8: Real exchange rate against the ECU/Euro in selected European economies, 1990-2007

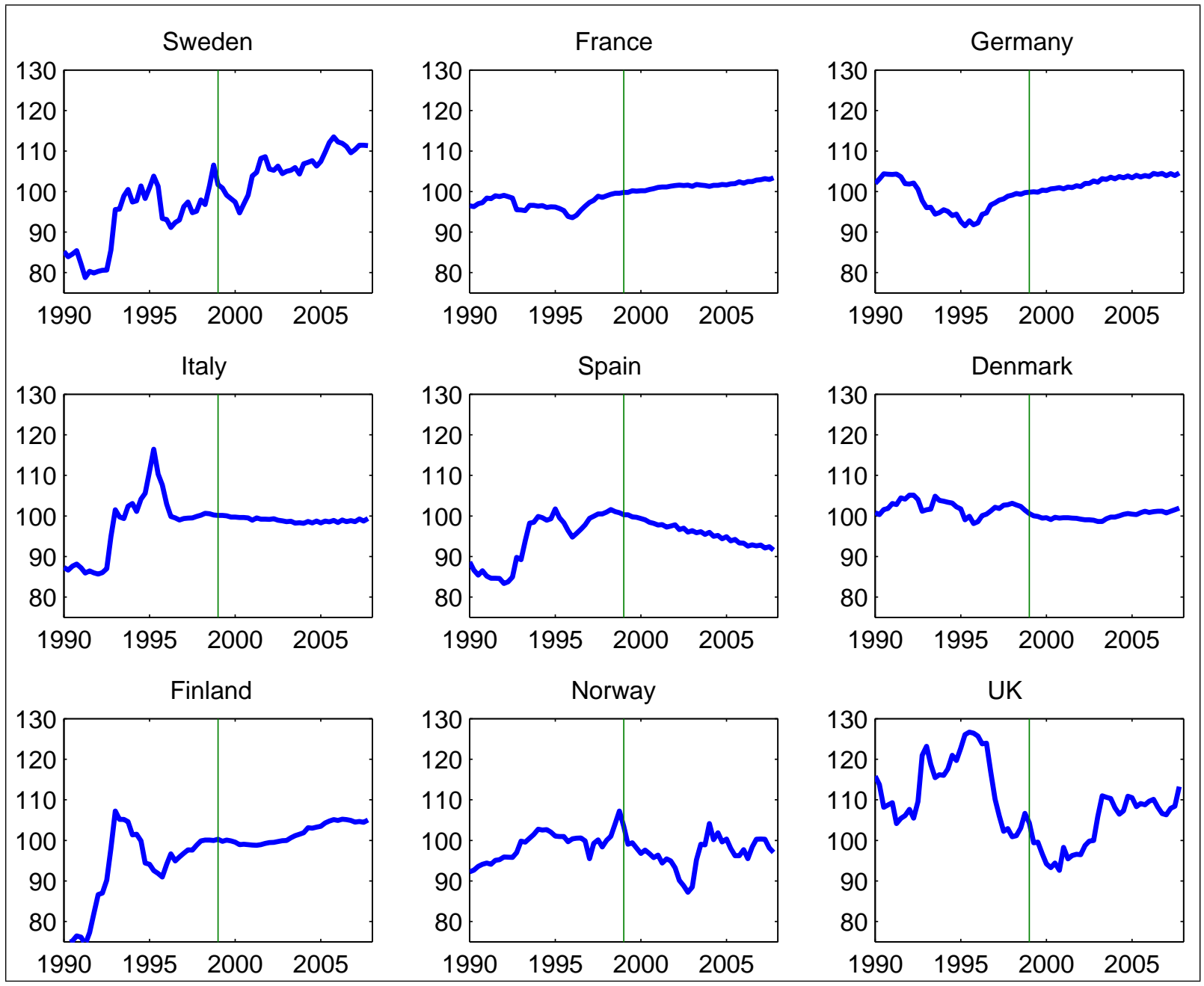

Note: Nominal exchange rate (domestic currency price of ECU/Euro) deflated by the consumer price level. Quarterly averages, $1999=100$. The vertical line represents the launch of EMU in January 1999. Source: Author's calculation based on data from the FRED data base, Federal Reserve Bank of St. Louis (nominal exchange rates) and OECD (consumer prices). 
Figure 9: Monetary policy rate, GDP growth rate, and CPI inflation rate in the Euro area and Sweden, 1999-2007

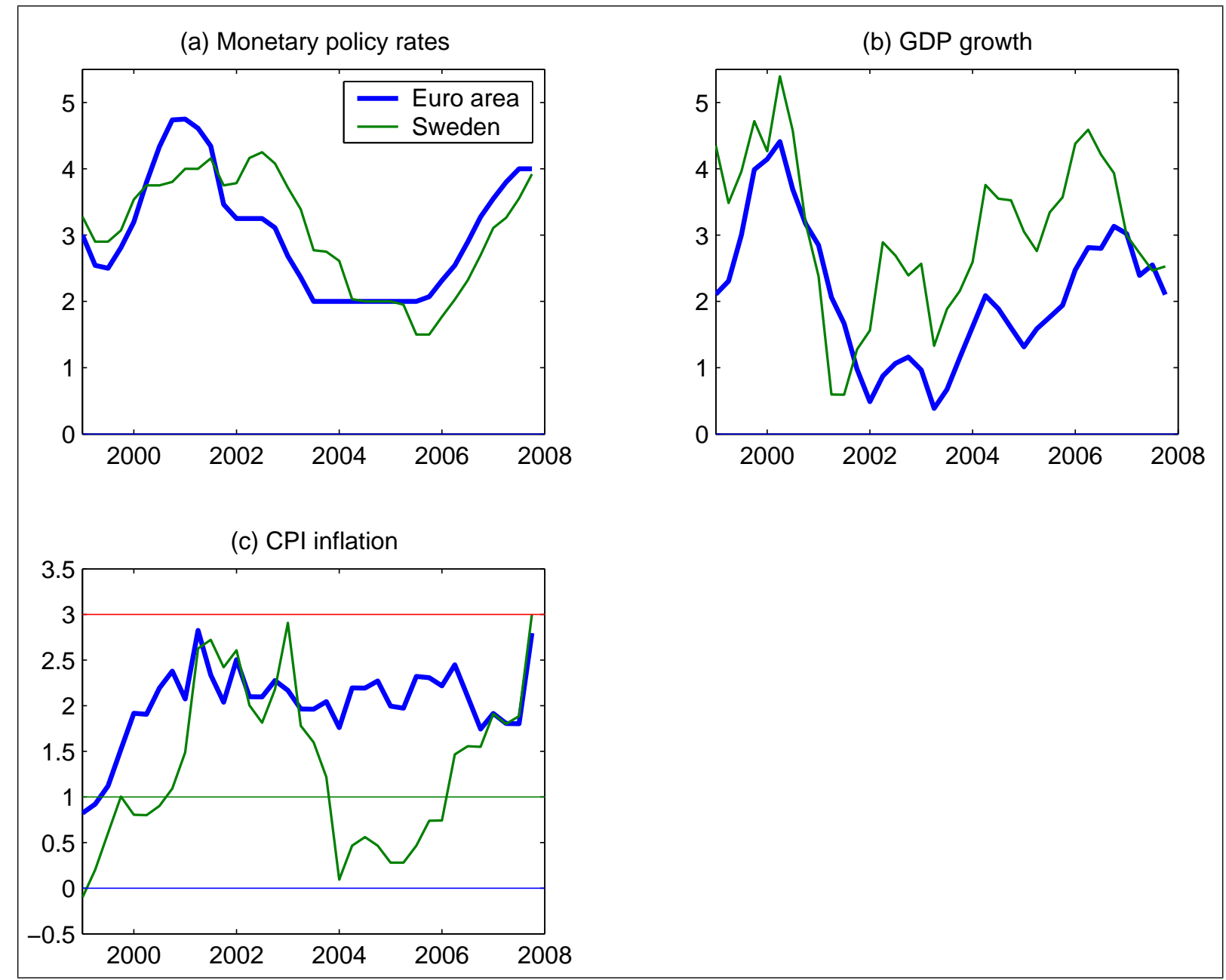

Note: ECB refinancing rate and Sveriges Riksbank repo rate, quarterly averages of daily data; Fourquarter GDP growth rate, quarterly data; Four-quarter CPI inflation rate, quarterly averages of monthly data. Percent per annum. The horizontal lines in panel (c) represent the Riksbank's inflation target range from one to three percent. Source: European Central Bank, Sveriges Riksbank, and OECD. 
Figure 10: The Swedish economy 1999-2005 according to actual data and the estimated model

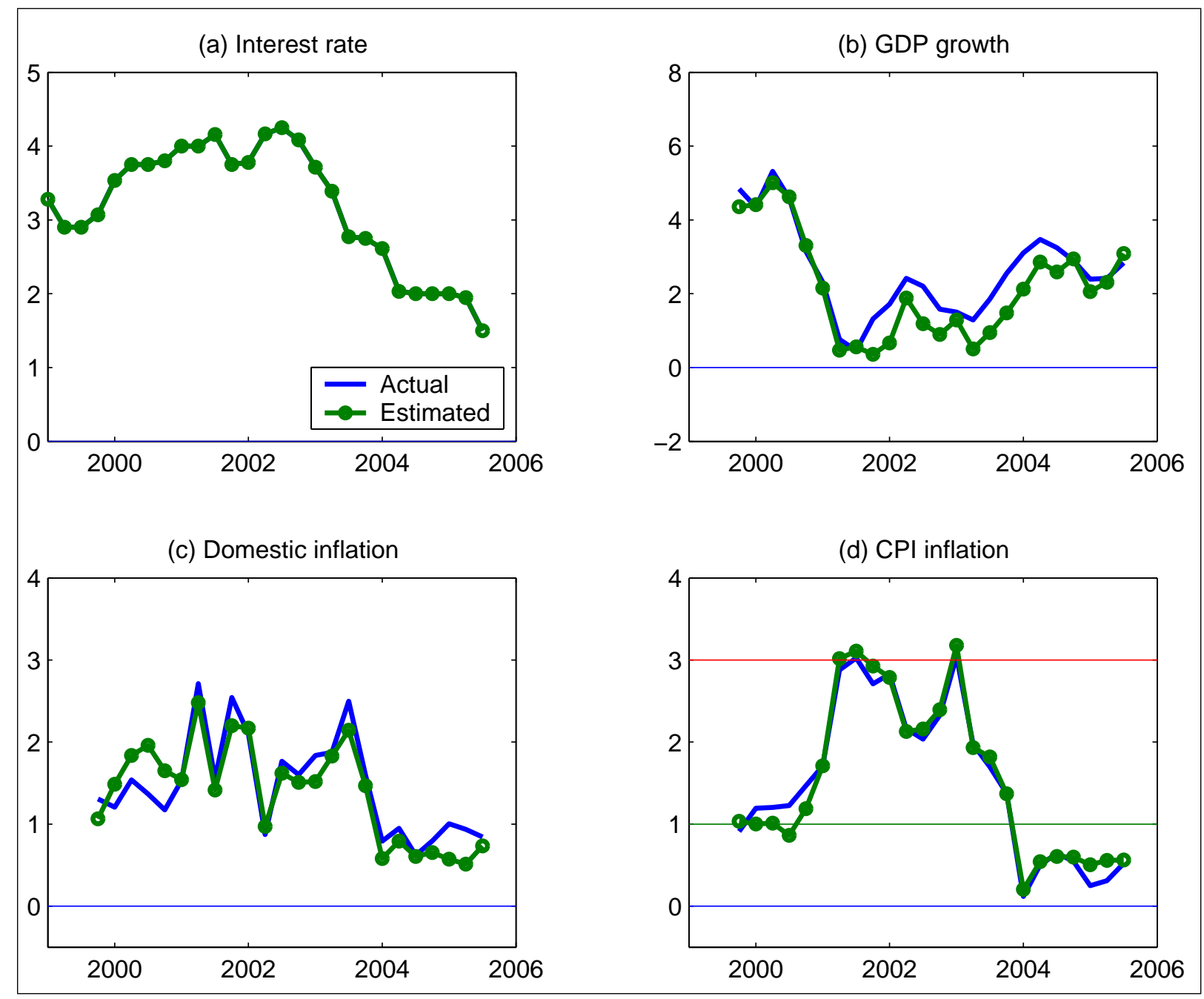

Note: Average quarterly data, four-quarter GDP growth rate and inflation rates, percent per annum. The horizontal lines in panel (d) represent the Riksbank's tolerance band around its two-percent inflation target. 
Figure 11: ECB interest rate 1999-2005 and the interest rate in the models with counterfactual monetary policy shocks or a counterfactual monetary policy rule

(a) Interest rate with counterfactual shocks

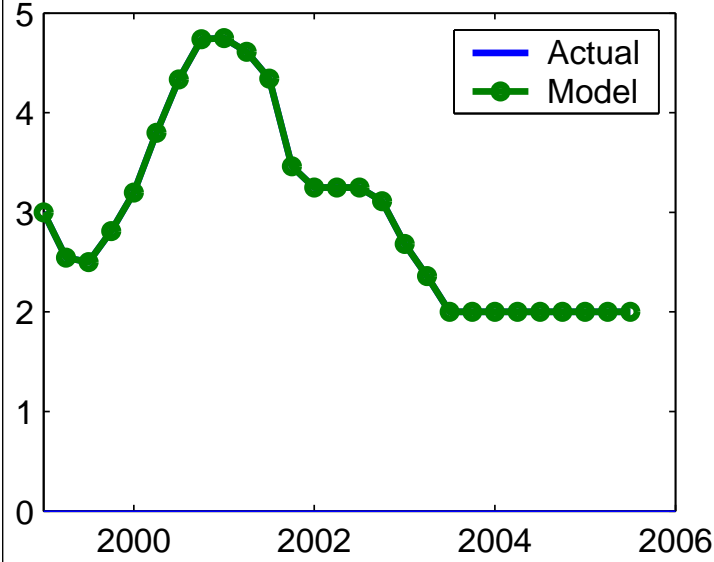

(c) Interest rate with counterfactual rule

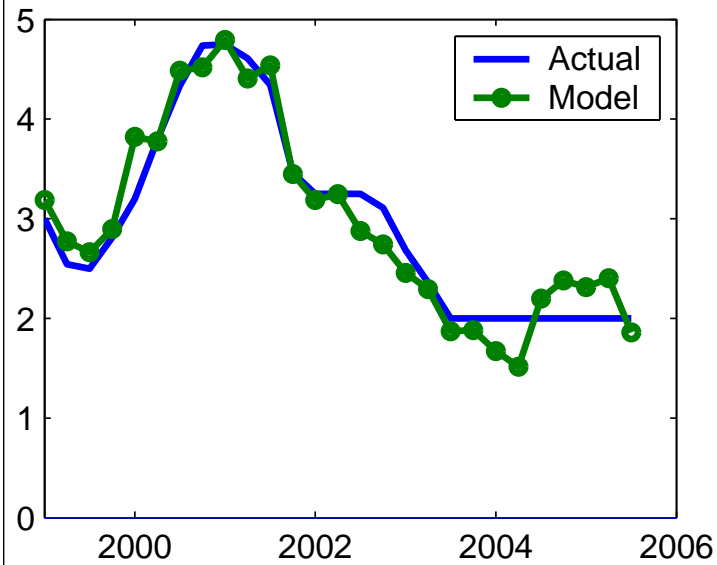

(b) Counterfactual monetary policy shocks

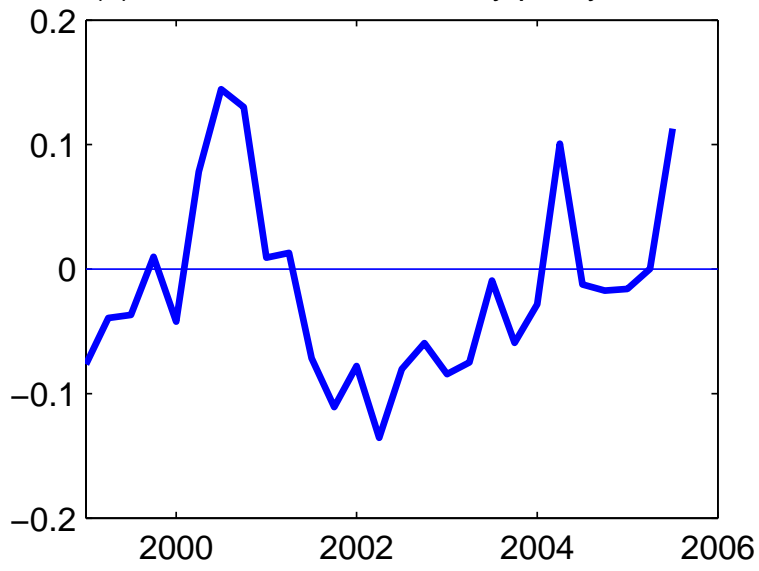

(d) Counterfactual rule deviations

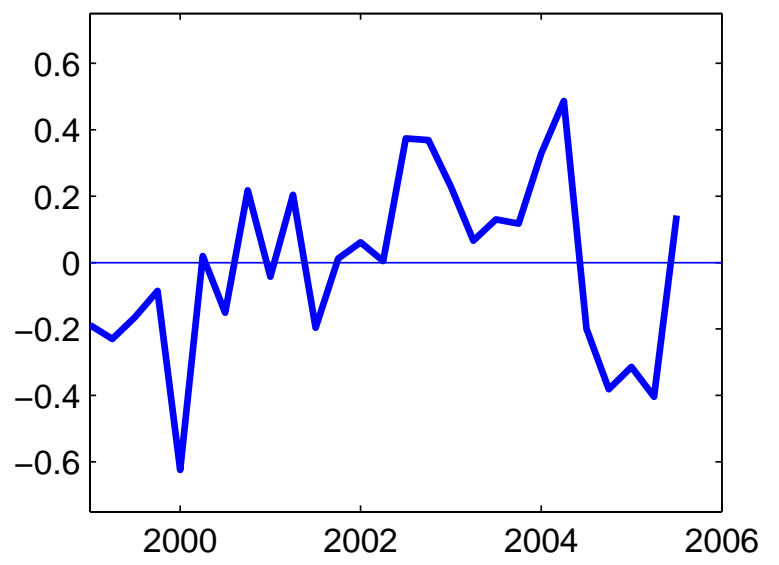

Note: Average quarterly data, percent per annum. 
Figure 12: The Swedish economy 1999-2005 according to the estimated model and the model with counterfactual monetary policy shocks

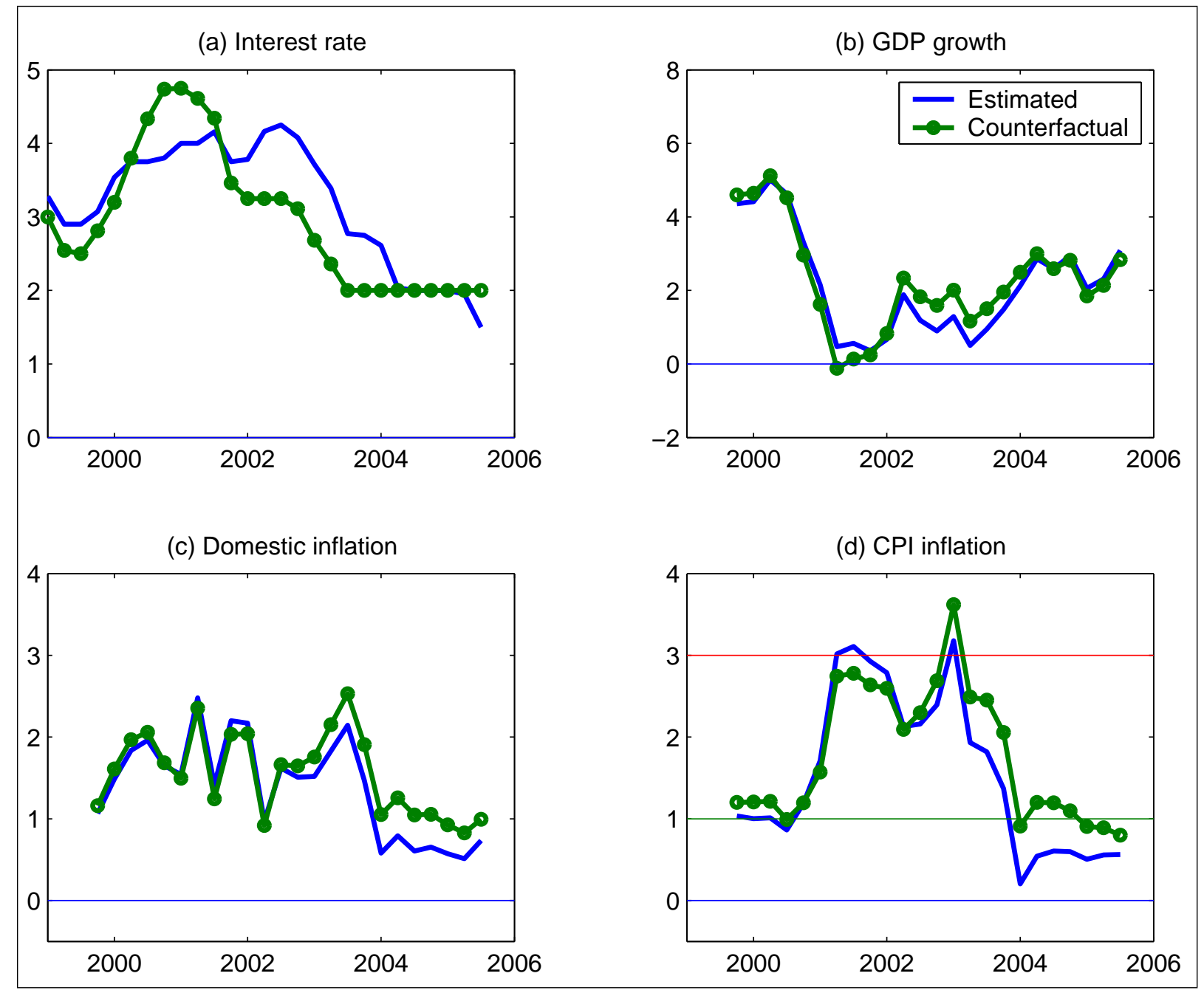

Note: Average quarterly data, four-quarter GDP growth rate and inflation rates, percent per annum. The horizontal lines in panel (d) represent the Riksbank's tolerance band around its two-percent inflation target. 
Figure 13: The Swedish economy 1999-2005 according to the estimated model and the model with a counterfactual monetary policy rule

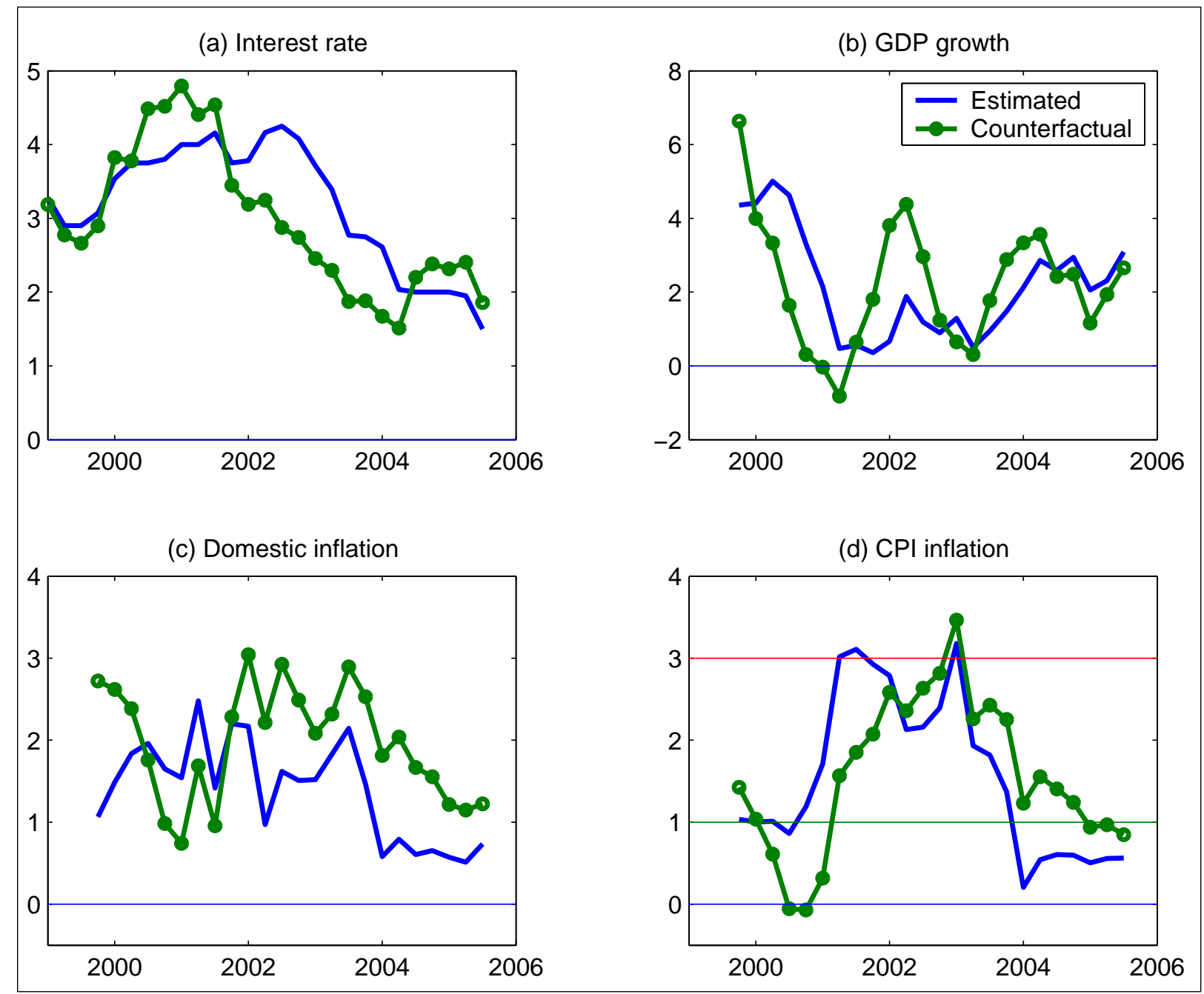

Note: Average quarterly data, four-quarter GDP growth rate and inflation rates, percent per annum. The horizontal lines in panel (d) represent the Riksbank's tolerance band around its two-percent inflation target. 


\section{Earlier Working Papers:}

For a complete list of Working Papers published by Sveriges Riksbank, see www.riksbank.se

Estimation of an Adaptive Stock Market Model with Heterogeneous Agents by Henrik Amilon ........ 2005:177

Some Further Evidence on Interest-Rate Smoothing: The Role of Measurement

Errors in the Output Gap by Mikael Apel and Per Jansson.....

Bayesian Estimation of an Open Economy DSGE Model with Incomplete Pass-Through

by Malin Adolfson, Stefan Laséen, Jesper Lindé and Mattias Villani

Are Constant Interest Rate Forecasts Modest Interventions? Evidence from

an Estimated Open Economy DSGE Model of the Euro Area by Malin Adolfson,

Stefan Laséen, Jesper Lindé and Mattias Villani

Inference in Vector Autoregressive Models with an Informative

Prior on the Steady State by Mattias Villani

Bank Mergers, Competition and Liquidity by Elena Carletti, Philipp Hartmann

and Giancarlo Spagnolo

Testing Near-Rationality using Detailed Survey Data

by Michael F. Bryan and Stefan Palmqvist.

Exploring Interactions between Real Activity and the Financial Stance

by Tor Jacobson, Jesper Lindé and Kasper Roszbach

Two-Sided Network Effects, Bank Interchange Fees,

and the Allocation of Fixed Costs by Mats A. Bergman .....

Trade Deficits in the Baltic States: How Long Will the Party Last?

by Rudolfs Bems and Kristian Jönsson.

Real Exchange Rate and Consumption Fluctuations follwing Trade Liberalization

by Kristian Jönsson

Modern Forecasting Models in Action: Improving Macroeconomic Analyses at Central Banks

by Malin Adolfson, Michael K. Andersson, Jesper Lindé, Mattias Villani and Anders Vredin.....

Bayesian Inference of General Linear Restrictions on the Cointegration Space by Mattias Villani.

2005:189

Forecasting Performance of an Open Economy Dynamic Stochastic General Equilibrium Model

by Malin Adolfson, Stefan Laséen, Jesper Lindé and Mattias Villani

Forecast Combination and Model Averaging using Predictive Measures

by Jana Eklund and Sune Karlsson.

Swedish Intervention and the Krona Float, 1993-2002

by Owen F. Humpage and Javiera Ragnartz

A Simultaneous Model of the Swedish Krona, the US Dollar and the Euro

by Hans Lindblad and Peter Sellin

Testing Theories of Job Creation: Does Supply Create Its Own Demand?

by Mikael Carlsson, Stefan Eriksson and Nils Gottfries.....

Down or Out: Assessing The Welfare Costs of Household Investment Mistakes

by Laurent E. Calvet, John Y. Campbell and Paolo Sodini

Efficient Bayesian Inference for Multiple Change-Point and Mixture Innovation Models

by Paolo Giordani and Robert Kohn

Derivation and Estimation of a New Keynesian Phillips Curve in a Small Open Economy

by Karolina Holmberg

Technology Shocks and the Labour-Input Response: Evidence from Firm-Level Data

by Mikael Carlsson and Jon Smedsaas

Monetary Policy and Staggered Wage Bargaining when Prices are Sticky

by Mikael Carlsson and Andreas Westermark

The Swedish External Position and the Krona by Philip R. Lane

Price Setting Transactions and the Role of Denominating Currency in FX Markets

by Richard Friberg and Fredrik Wilander.....

The geography of asset holdings: Evidence from Sweden

by Nicolas Coeurdacier and Philippe Martin

Evaluating An Estimated New Keynesian Small Open Economy Model

by Malin Adolfson, Stefan Laséen, Jesper Lindé and Mattias Villani .......

The Use of Cash and the Size of the Shadow Economy in Sweden

by Gabriela Guibourg and Björn Segendorf

Bank supervision Russian style: Evidence of conflicts between micro- and macro-

prudential concerns by Sophie Claeys and Koen Schoors 
Optimal Monetary Policy under Downward Nominal Wage Rigidity

by Mikael Carlsson and Andreas Westermark

Financial Structure, Managerial Compensation and Monitoring

by Vittoria Cerasi and Sonja Daltung

Financial Frictions, Investment and Tobin's q by Guido Lorenzoni and Karl Walentin 2007:208

Sticky Information vs. Sticky Prices: A Horse Race in a DSGE Framework

by Mathias Trabandt.

Acquisition versus greenfield: The impact of the mode of foreign bank entry

on information and bank lending rates by Sophie Claeys and Christa Hainz $2007: 210$

Nonparametric Regression Density Estimation Using Smoothly Varying Normal Mixtures by Mattias Villani, Robert Kohn and Paolo Giordani

The Costs of Paying - Private and Social Costs of Cash and Card

by Mats Bergman, Gabriella Guibourg and Biörn Segendorf.

Using a New Open Economy Macroeconomics model to make real nominal

exchange rate forecasts by Peter Sellin

Introducing Financial Frictions and Unemployment into a Small Open Economy Model

by Lawrence J. Christiano, Mathias Trabandt and Karl Walentin.

Earnings Inequality and the Equity Premium by Karl Walentin

2007:215

Bayesian forecast combination for VAR models by Michael $K$ Andersson and Sune Karlsson

2007:216

Do Central Banks React to House Prices?

by Daria Finocchiaro and Virginia Queijo von Heideken

The Riksbank's Forecasting Performance

by Michael K. Andersson, Gustav Karlsson and Josef Svensson

Macroeconomic Impact on Expected Default Freqency

by Per Åsberg and Hovick Shahnazarian

Monetary Policy Regimes and the Volatility of Long-Term Interest Rates

by Virginia Queijo von Heideken

Governing the Governors: A Clinical Study of Central Banks

by Lars Frisell, Kasper Roszbach and Giancarlo Spagnolo

The Monetary Policy Decision-Making Process and the Term Structure of Interest Rates

by Hans Dillén

How Important are Financial Frictions in the U.S. and the Euro Area

by Virginia Queijo von Heideken

Block Kalman filtering for large-scale DSGE models by Ingvar Strid and Karl Walentin 2008:224

Optimal Monetary Policy in an Operational Medium-Sized DSGE Model

by Malin Adolfson, Stefan Laséen, Jesper Lindé and Lars E.O. Svensson $2008: 225$

Firm Default and Aggregate Fluctuations by Tor Jacobson, Rikard Kindell, Jesper Lindé and Kasper Roszbach..... 
Sveriges Riksbank

Visiting address: Brunkebergs torg 11

Mail address: se-103 37 Stockholm

Website: www.riksbank.se 